Prepared in cooperation with the U.S. Army Corps of Engineers, Fort Worth District; City of Corpus Christi; Guadalupe-Blanco River Authority; San Antonio River Authority; and San Antonio Water System

\title{
Simulation of Streamflow, Evapotranspiration, and Groundwater Recharge in the Middle Nueces River Watershed, South Texas, 1961-2008
}

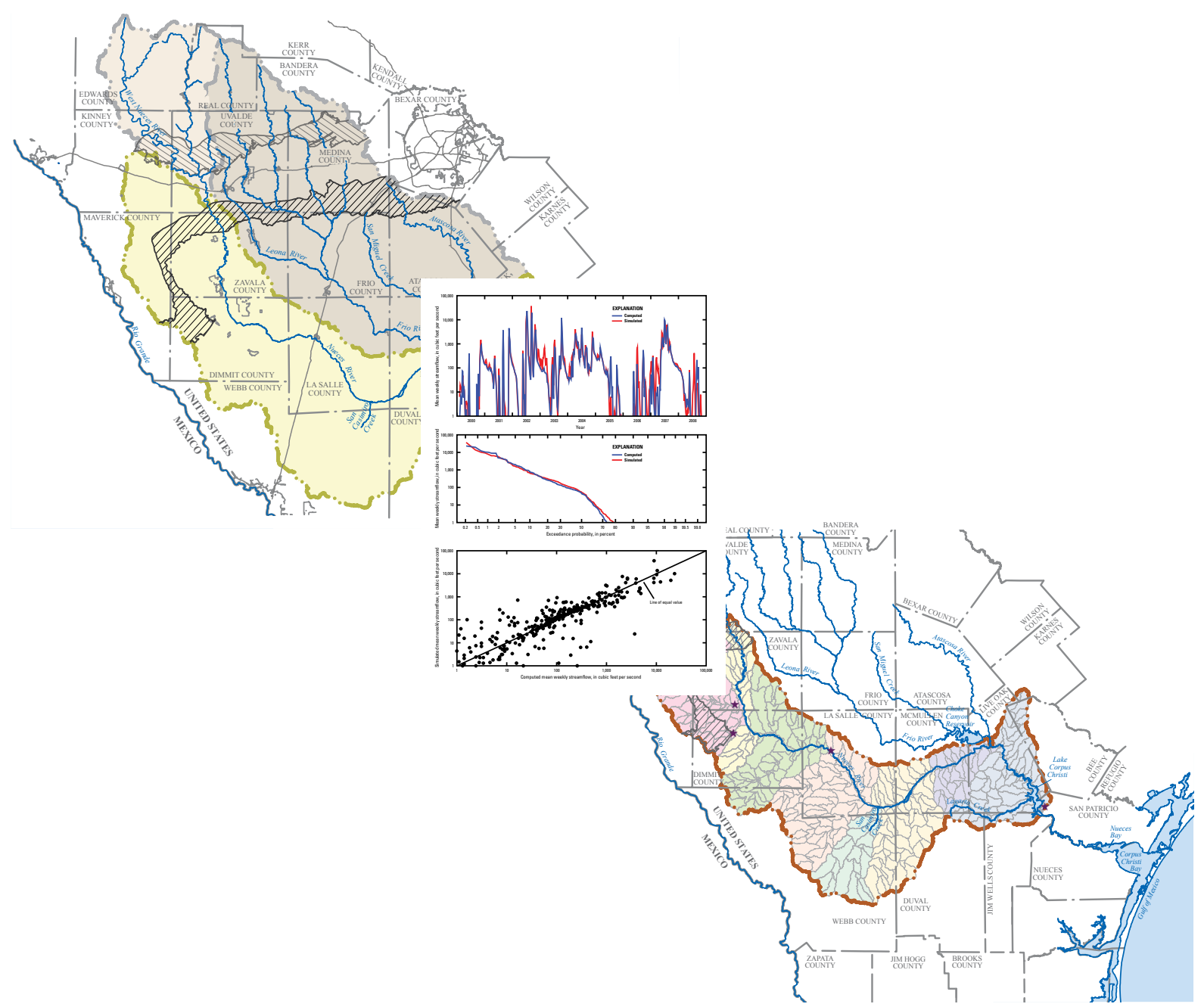

Scientific Investigations Report 2012-5136 



\section{Simulation of Streamflow, Evapotranspiration, and Groundwater Recharge in the Middle Nueces River Watershed, South Texas, 1961-2008}

By Benjamin J. Dietsch and Loren L. Wehmeyer

Prepared in cooperation with the U.S. Army Corps of Engineers, Fort Worth

District; City of Corpus Christi; Guadalupe-Blanco River Authority;

San Antonio River Authority; and San Antonio Water System

Scientific Investigations Report 2012-5136 


\title{
U.S. Department of the Interior \\ KEN SALAZAR, Secretary \\ U.S. Geological Survey \\ Marcia K. McNutt, Director
}

\section{U.S. Geological Survey, Reston, Virginia: 2012}

\author{
This and other USGS information products are available at http://store.usgs.gov/ \\ U.S. Geological Survey \\ Box 25286, Denver Federal Center \\ Denver, CO 80225 \\ To learn about the USGS and its information products visit http://www.usgs.gov/ \\ 1-888-ASK-USGS
}

\footnotetext{
Any use of trade, product, or firm names is for descriptive purposes only and does not imply endorsement by the U.S. Government.

Although this report is in the public domain, permission must be secured from the individual copyright owners to reproduce any copyrighted materials contained within this report.
}

Suggested citation:

Dietsch, B.J., and Wehmeyer, L.L., 2012, Simulation of streamflow, evapotranspiration, and groundwater recharge in the middle Nueces River watershed, south Texas, 1961-2008: U.S. Geological Survey Scientific Investigations Report 2012-5136, 37 p. 


\section{Contents}

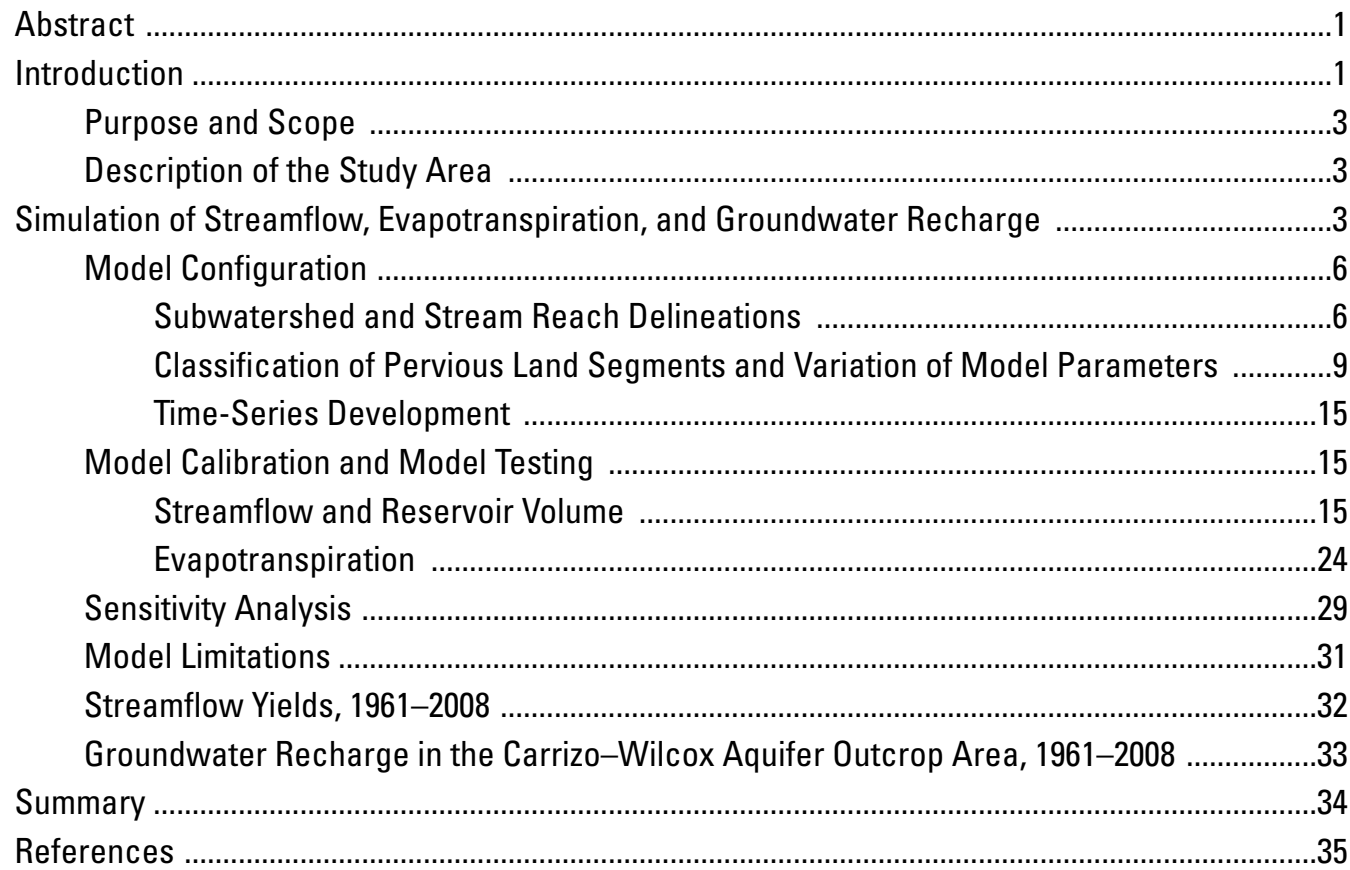

\section{Figures}

1. Map showing Nueces River watershed, south Texas

2. Map showing land cover in the middle Nueces River watershed, south Texas, determined by using Landsat imagery compiled and published in 2001 for the National Land Cover Database

3. Map showing locations of data-collection stations that provided data for the Hydrological Simulation Program-FORTRAN model of the middle Nueces River watershed, south Texas

4. Hydrological Simulation Program-FORTRAN (HSPF) flowchart for hydrologic processes for pervious land segments

5. Map showing subwatershed and stream and reservoir reach delineation for the Hydrological Simulation Program-FORTRAN model of the middle Nueces River watershed, south Texas

6. Map showing streams or reservoir reaches and associated drainage areas for the Mathis subwatershed used in the Hydrological Simulation Program-FORTRAN model of the middle Nueces River watershed, south Texas

7. Map showing relative soil infiltration rates in the middle Nueces River watershed, south Texas

8. Map showing locations of National Weather Service meteorological stations and associated Thiessen areas

9. Graphs showing computed and simulated mean weekly streamflow at streamflowgaging station 08193000 Nueces River near Asherton, Texas, 2000-8

10. Graphs showing computed and simulated mean weekly streamflow at streamflowgaging station 08194000 Nueces River at Cotulla, Texas, 2000-8 
11. Graphs showing computed and simulated mean weekly streamflow at streamflowgaging station 08194500 Nueces River near Tilden, Texas, 2000-8

12. Graphs showing computed and simulated mean weekly streamflow at streamflowgaging station 08210000 Nueces River near Three Rivers, Texas, 2000-8

13. Graphs showing computed and simulated mean weekly reservoir volume of Lake Corpus Christi, south Texas, 1992-2008

14. Graphs showing computed weekly evapotranspiration at U.S. Geological Survey 290810099212100 southwest Medina County meteorological station near D'Hanis, Texas, and weekly evapotranspiration simulated by using the Hydrological Simulation Program-FORTRAN model for the Carrizo-Wilcox aquifer outcrop area in the Sycamore and Asherton subwatersheds of the middle Nueces River watershed, south Texas, October 2006-December 2008

\section{Tables}

1. National Weather Service meteorological stations from which data were obtained for the Hydrological Simulation Program-FORTRAN model of the middle Nueces River watershed, south Texas, 1961-2008

2. Annual rainfall at selected National Weather Service meteorological stations in the middle Nueces River watershed, south Texas, 1961-2008

3. U.S. Geological Survey stations where data were obtained for the Hydrological Simulation Program-FORTRAN model of the middle Nueces River watershed, south Texas

4. Subwatersheds of the Hydrological Simulation Program-FORTRAN model of the middle Nueces River watershed, south Texas

5. Wastewater discharges included in the Hydrological Simulation ProgramFORTRAN model of the middle Nueces River watershed, south Texas

6. Active water rights (2010) included in the Hydrological Simulation ProgramFORTRAN model of the middle Nueces River watershed, south Texas

7. Calibrated values for selected parameters, by subwatershed, for the Hydrological Simulation Program-FORTRAN model of the middle Nueces River watershed, south Texas

8. Streamflow calibration and testing results for the Hydrological Simulation Program-FORTRAN model of the middle Nueces River watershed, south Texas .18

9. Sensitivity of the estimated mean annual evapotranspiration, groundwater recharge, and surface runoff for the Carrizo-Wilcox aquifer outcrop to changes in selected model parameters of the Hydrological Simulation Program-FORTRAN model of the Sycamore subwatershed, south Texas, 2000-8

10. Simulated mean annual streamflow volumes and yields generated from subwatersheds in the Hydrological Simulation Program-FORTRAN model of the middle Nueces River watershed, south Texas, 1961-2008

11. Estimated annual rainfall, evapotranspiration, groundwater recharge, and surface runoff for the Carrizo-Wilcox aquifer outcrop area in the middle Nueces River watershed, south Texas, 1961-2008. 


\section{Conversion Factors}

\section{Inch/Pound to SI}

\begin{tabular}{lcl}
\hline \multicolumn{1}{c}{ Multiply } & By & \multicolumn{1}{c}{ To obtain } \\
\hline inch (in) & Length & \\
inch (in) & 2.54 & centimeter $(\mathrm{cm})$ \\
foot (ft) & 25.4 & millimeter $(\mathrm{mm})$ \\
mile (mi) & 0.3048 & meter $(\mathrm{m})$ \\
\hline & 1.609 & kilometer $(\mathrm{km})$ \\
\hline acre & Area & \\
square mile $\left(\mathrm{mi}^{2}\right)$ & 4,047 & square meter $\left(\mathrm{m}^{2}\right)$ \\
\hline & 2.590 & square $\mathrm{kilometer}\left(\mathrm{km}^{2}\right)$ \\
\hline acre-foot $(\mathrm{acre}-\mathrm{ft})$ & Volume & \\
\hline & 1,233 & cubic meter $\left(\mathrm{m}^{3}\right)$ \\
\hline cubic foot per second $\left(\mathrm{ft}^{3} / \mathrm{s}\right)$ & Flow rate & cubic meter per second $\left(\mathrm{m}^{3} / \mathrm{s}\right)$ \\
million gallons per day $(\mathrm{Mgal} / \mathrm{d})$ & 0.02832 & cubic meter per second $\left(\mathrm{m}^{3} / \mathrm{s}\right)$ \\
inch per year (in/yr) & 0.04391 & millimeter per year $\left(\mathrm{mm}^{2} / \mathrm{yr}\right)$ \\
\hline
\end{tabular}

Vertical coordinate information is referenced to the National Geodetic Vertical Datum of 1929 (NGVD 29).

Horizontal coordinate information is referenced to the North American Datum of 1983 (NAD 83). 



\title{
Simulation of Streamflow, Evapotranspiration, and Ground water Recharge in the Middle Nueces River Watershed, South Texas, 1961-2008
}

\author{
By Benjamin J. Dietsch and Loren L. Wehmeyer
}

\section{Abstract}

The U.S. Geological Survey-in cooperation with the U.S. Army Corps of Engineers, Fort Worth District; City of Corpus Christi; Guadalupe-Blanco River Authority; San Antonio River Authority; and San Antonio Water Systemconfigured, calibrated, and tested a watershed model for a study area consisting of about 7,726 square miles of the middle Nueces River watershed in south Texas. The purpose of the model is to contribute to the understanding of watershed processes and hydrologic conditions in the middle Nueces River watershed. The model simulates streamflow, evapotranspiration, and groundwater recharge by using a numerical representation of physical characteristics of the landscape and meteorological and streamflow data.

Model simulations of streamflow, evapotranspiration, and groundwater recharge were performed for various periods of record depending upon available gaged data for input and comparison, starting as early as 1961 . Because of the large size of the study area, the middle Nueces River watershed was divided into eight subwatersheds, and separate Hydrological Simulation Program-FORTRAN models were developed for each subwatershed. Simulation of the overall study area involved running simulations in downstream order. Output from the model was summarized by subwatershed, point locations, stream and reservoir reaches, and the CarrizoWilcox aquifer outcrop area. Four long-term U.S. Geological Survey streamflow-gaging stations were used for streamflow model calibration and testing with data from 1990 to 2008 . Monthly evaporation estimates from 2001 to 2008 and waterlevel data from 1961 to 2008 at Lake Corpus Christi also were used for model calibration. Additionally, evapotranspiration data for 2006-8 from a U.S. Geological Survey meteorological station in Medina County were used for calibration.

Streamflow calibrations were considered poor to very good. The $2000-8$ calibration results were characterized as good to very good for total flow volumes and for the volume of the highest 10 percent of daily flows. Calibration results for streamflow volumes of the lowest 50 percent of daily flows were considered poor. The daily streamflow calibration at U.S. Geological Survey streamflow-gaging station 08210000
Nueces River near Three Rivers, Tex., had the lowest (best) root mean square error, and U.S. Geological Survey streamflow-gaging station 08194500 Nueces River near Tilden, Tex., had the highest root mean square error expressed as a percentage of the mean flow rate. The mean daily reservoir volume during 1961-2008 was 182,000 acre-feet. Simulated mean daily reservoir volume was within 9 percent of this computed volume.

Selected results of the model include streamflow yields for the subwatersheds and water-balance information for the Carrizo-Wilcox aquifer outcrop area. For the entire model domain, the area-weighted mean streamflow yield from 1961 to 2008 was 1.12 inches/year. The mean annual rainfall on the outcrop area during the 1961-2008 simulation period was 21.7 inches. Of this rainfall, an annual mean of 20.1 inches (about 93 percent) was simulated as evapotranspiration, 1.2 inches (about 6 percent) was simulated as groundwater recharge, and 0.5 inches (about 2 percent) was simulated as surface runoff.

\section{Introduction}

The Nueces River rises in Edwards County northeast of Brackettville, Texas, and flows generally southeast approximately 315 miles (mi) to where it empties into Nueces Bay near Corpus Christ, Tex., draining approximately 16,700 square miles $\left(\mathrm{mi}^{2}\right)$. The $7,726-\mathrm{mi}^{2}$ middle Nueces River watershed begins in Kinney County, Tex. (north of the Carrizo-Wilcox aquifer outcrop area), and ends at the outflow from Lake Corpus Christi, Tex. (fig. 1).

The U.S. Army Corps of Engineers, Fort Worth District, began studying the Nueces River Basin in 2002 to identify opportunities for ecosystem restoration. Several potential restoration activities were identified including aquifer recharge enhancement, flood-damage reduction, and enhanced watershed management using multipurpose projects (HDR Engineering, 2002). The first phase of the U.S. Army Corps of Engineers study consisted of working with various Federal, State, and local partners to determine and document the existing hydrologic, engineering, economic, 


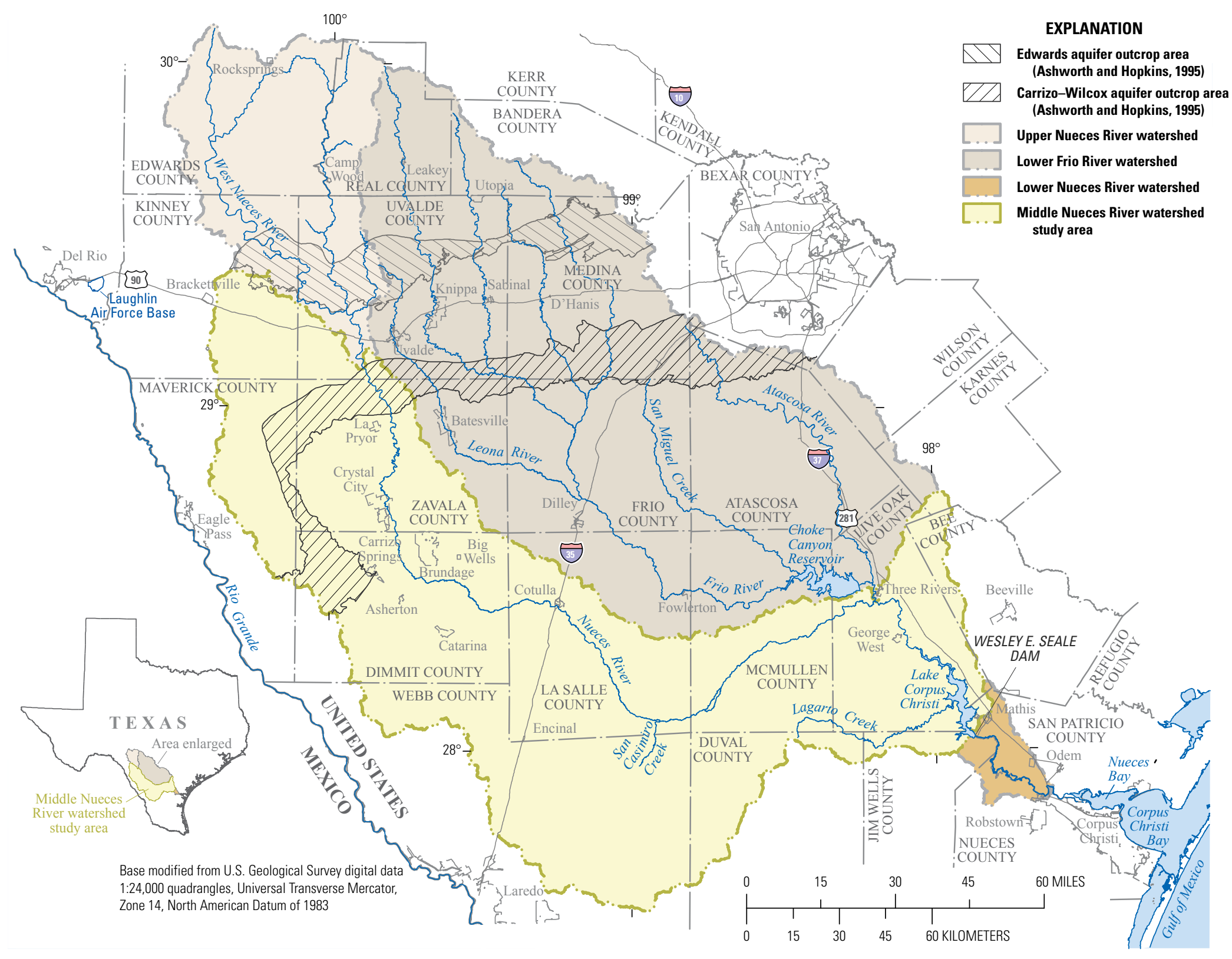

Figure 1. Nueces River watershed, south Texas. 
and environmental conditions of the Nueces River watershed. As part of this phase of the study, the U.S. Geological Survey (USGS) - in cooperation with the U.S. Army Corps of Engineers, Fort Worth District; City of Corpus Christi; Guadalupe-Blanco River Authority; San Antonio River Authority; and San Antonio Water System - developed a hydrologic model of the middle Nueces River watershed. The middle Nueces River watershed begins north of the CarrizoWilcox aquifer outcrop area and extends south to the outflow of Lake Corpus Christi, excluding Choke Canyon Reservoir tributary watersheds and the Atascosa River watershed (fig. 1). The middle Nueces River watershed model was designed to simulate streamflow, evapotranspiration, and groundwater recharge in the study area and contributes to the understanding of watershed processes and hydrologic conditions in the Nueces River Basin.

\section{Purpose and Scope}

This report describes the simulation of streamflow, evapotranspiration, and groundwater recharge in the middle Nueces River watershed. A Hydrological Simulation Program-FORTRAN (HSPF) watershed model, developed by using data collected during 1961-2008, is used to simulate streamflow, evapotranspiration, and groundwater recharge for the same period. The functionality of the HSPF software and the input data are described, followed by the configuration, calibration, and testing of the middle Nueces River watershed model. Limitations of model-simulated estimates of streamflow, evapotranspiration, and groundwater recharge are described. The wording and presentation of material in this report is based on a previous USGS report (Lizárraga and Ockerman, 2011); the contents of each section are modified from this previous report.

\section{Description of the Study Area}

The 7,726-mi middle Nueces River watershed (hereinafter referred to as the "study area") includes parts of 14 counties in Texas: Bee, Dimmit, Duval, Jim Wells, Karnes, Kinney, La Salle, Live Oak, Maverick, McMullen, San Patricio, Uvalde, Webb, and Zavala. Approximately $464 \mathrm{mi}^{2}$ of the Carrizo-Wilcox aquifer outcrop area, as defined by the Texas Water Development Board (Ashworth and Hopkins, 1995), is within the study area (fig. 1). In 2009, Crystal City, Tex. (fig. 1), was the largest city in the study area, with approximately 7,190 residents (U.S. Census Bureau, 2009). The study area has historically been undeveloped rangeland (scrub, grassland) and cropland. Land cover in the study area (fig. 2) was determined by using Landsat imagery compiled for the National Land Cover Database (Homer and others, 2004; Multi-Resolution Land Characteristics Consortium, 2010).

Most of the rainfall in the study area typically occurs in the form of intense, isolated storms during the spring, early summer, and fall (Larkin and Bomar, 1983). National Weather
Service (NWS) meteorological data were compiled for the study area for 1961-2008 (National Climatic Data Center, 2009). Mean annual rainfall measured during 1961-2008 at 11 NWS meteorological stations in or near the study area (fig. 3; tables 1 and 2) ranged from 21.0 to 32.2 inches (in). About 92 percent of the rainfall in the region evapotranspires each year (Lizárraga and Ockerman, 2011). Rainfall events associated with hurricanes and tropical storms that make landfall on the Texas coast are capable of producing rainfall intensities of more than 12 inches in one hour in south Texas, which are among the largest rainfall intensities found anywhere on earth (Asquith, 1998).

Many small, ungaged streams enter the Nueces River from Uvalde County downstream to the confluence with the Frio River. There are nine USGS streamflow-gaging stations within the study area: seven streamflow-gaging stations on the main stem of the Nueces River with daily streamflow recorded during 1961-2008 (fig. 3, table 3, sites Q1-Q3, Q5, Q6, Q8, and Q9) and two on tributaries (sites Q4 and Q7) with daily streamflow recorded during 1962-2008 and 1971-2008, respectively.

When Lake Corpus Christi was constructed by the Civilian Conservation Corps in 1935, it had a surface area of 5,493 acres and a storage volume of 43,800 acre-feet (Texas Water Development Board, 2002). Lake Corpus Christi was enlarged in 1958 when the Wesley E. Seale Dam replaced the original Mathis Dam (City of Corpus Christi, 2010). In 2002, a volumetric survey estimated that the reservoir encompassed 18,286 acres and contained a volume of 257,260 acre-feet at the normal pool elevation of 94.0 feet (Texas Water Development Board, 2003). The City of Corpus Christi is legally obligated (Texas Natural Resource Conservation Commission, 2001) to allow some freshwater to "pass through" the Choke Canyon and Lake Corpus Christi reservoir system to Nueces Bay (fig. 1). USGS streamflow-gaging station 08211000 Nueces River near Mathis, Tex. (fig. 3, site Q9), is used to measure the releases made from the reservoir system to meet the pass-through release requirements. Streamflow at that site has ranged from 0.2 to 125,000 cubic feet per second $\left(\mathrm{ft}^{3} / \mathrm{s}\right)$ during the period of computed streamflow from the reservoir (1939-2010) (U.S. Geological Survey, 2011). The computed streamflow data described in this report are based on measurements of stage and velocity at the station and a stage-discharge relation (Rantz and others, 1982).

\section{Simulation of Streamflow, Evapotranspiration, and Groundwater Recharge}

The Hydrological Simulation Program-FORTRAN (HSPF), version 12 (Bicknell and others, 2001) was used to simulate streamflow, evapotranspiration, and groundwater recharge in the middle Nueces River watershed. HSPF is 


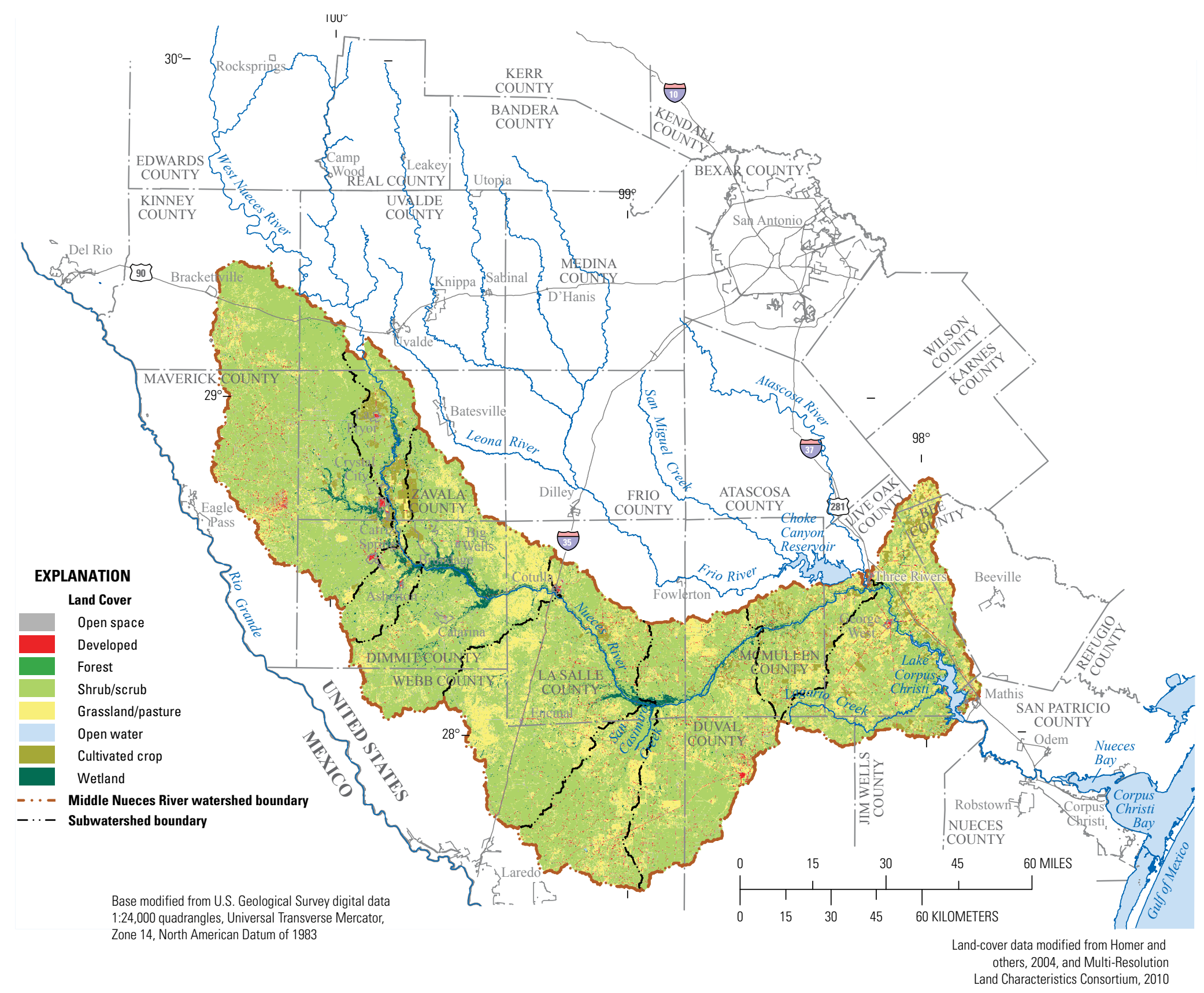

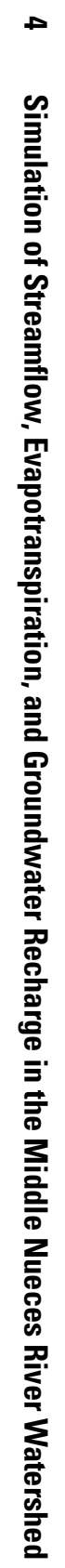

Figure 2. Land cover in the middle Nueces River watershed, south Texas, determined by using Landsat imagery compiled and published in 2001 for the National Land Cover Database. 


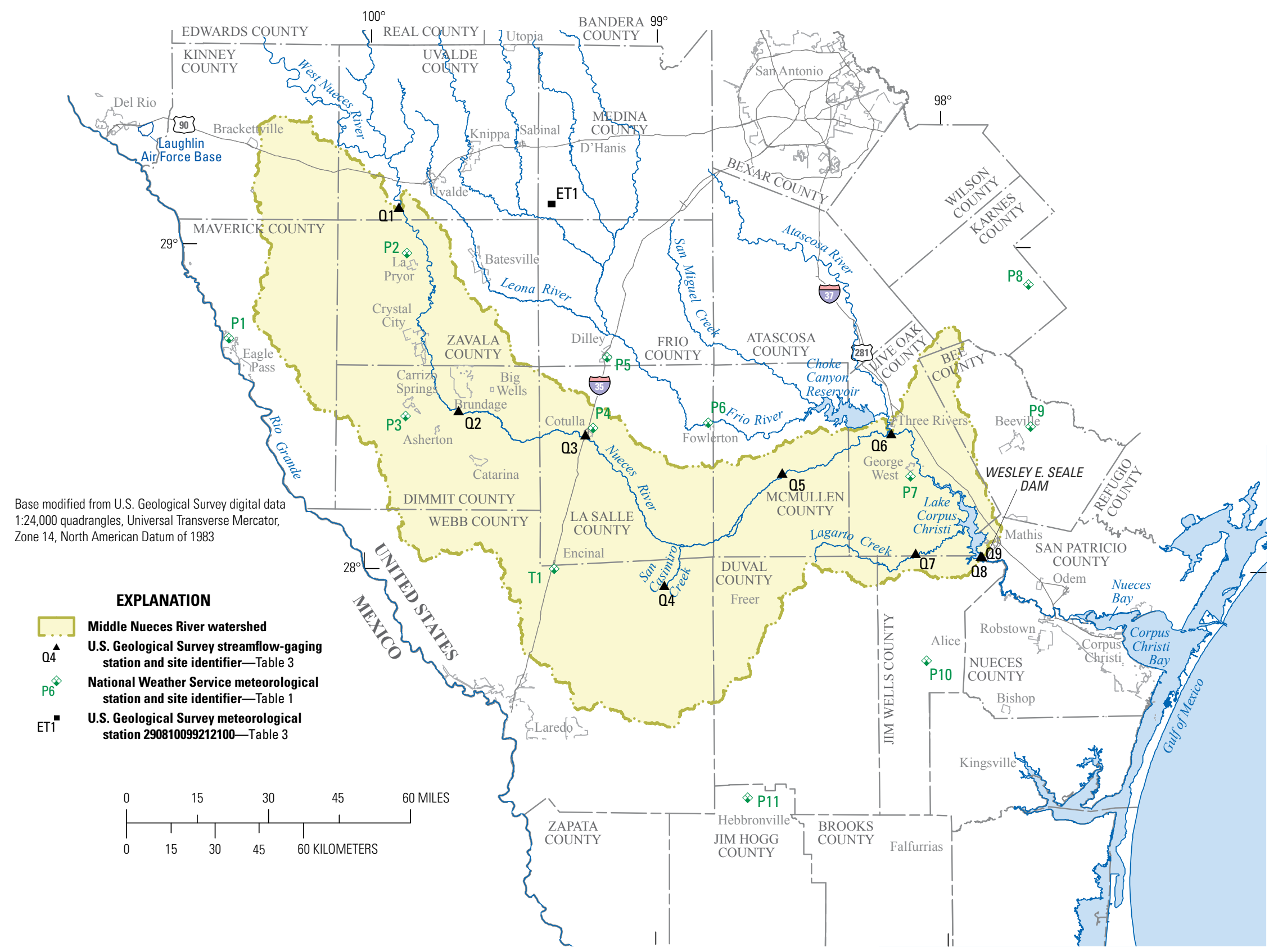

Figure 3. Locations of data-collection stations that provided data for the Hydrological Simulation Program—FORTRAN model of the middle Nueces River watershed, south 
Table 1. National Weather Service meteorological stations from which data were obtained for the Hydrological Simulation ProgramFORTRAN model of the middle Nueces River watershed, south Texas, 1961-2008.

[NWS, National Weather Service; dd, degrees; mm, minutes; ss, seconds; --, not available; R, rainfall; T, air temperature]

\begin{tabular}{|c|c|c|c|c|c|c|}
\hline $\begin{array}{c}\text { NWS site } \\
\text { identifier } \\
\text { (fig. 3) }\end{array}$ & $\begin{array}{c}\text { NWS station } \\
\text { number and name }\end{array}$ & $\begin{array}{l}\text { Latitude } \\
\text { (ddmmss) }\end{array}$ & $\begin{array}{l}\text { Longitude } \\
\text { (ddmmss) }\end{array}$ & $\begin{array}{l}\text { Type of } \\
\text { data }\end{array}$ & $\begin{array}{l}\text { Period } \\
\text { of record } \\
\text { obtained }\end{array}$ & $\begin{array}{l}\text { Priority of NWS } \\
\text { stations used to } \\
\text { fill missing record }\end{array}$ \\
\hline $\mathrm{P} 1$ & 412679 Eagle Pass, Tex. & $28^{\circ} 43^{\prime}--^{\prime \prime}$ & $100^{\circ} 29^{\prime}--^{\prime \prime}$ & $\mathrm{R}, \mathrm{T}$ & $1961-2008$ & $411486,414920,412458$ \\
\hline $\mathrm{P} 2$ & 414920 La Pryor, Tex. & $28^{\circ} 59^{\prime}--^{\prime \prime}$ & $99^{\circ} 52^{\prime}--^{\prime \prime}$ & $\mathrm{R}$ & $\begin{array}{l}1961-1987 \\
1989-2008\end{array}$ & $412679,411486,412458$ \\
\hline P3 & 411486 Carrizo Springs 3W, Carrizo Springs, Tex. & $28^{\circ} 29^{\prime}--"$ & $99^{\circ} 52^{\prime}--{ }^{\prime \prime}$ & $\mathrm{R}$ & $1961-2008$ & $414920,412679,412048$ \\
\hline $\mathrm{P} 4$ & 412048 Cotulla La Salle County Airport & $28^{\circ} 27^{\prime}--^{\prime \prime}$ & $99^{\circ} 13^{\prime}--{ }^{\prime \prime}$ & $\mathrm{R}$ & $1961-2008$ & $412458,413299,411486$ \\
\hline P5 & 412458 Dilley, Tex. & $28^{\circ} 40^{\prime--"}$ & $99^{\circ} 10^{\prime--"}$ & $\mathrm{R}, \mathrm{T}$ & $\begin{array}{l}1961-2008 \\
1916-2008\end{array}$ & $412048,413299,411486$ \\
\hline P6 & 413299 Fowlerton, Tex. & $28^{\circ} 28^{\prime}--^{\prime \prime}$ & $98^{\circ} 49^{\prime}--^{\prime \prime}$ & $\mathrm{R}$ & $1961-2008$ & $412048,412458,413508$ \\
\hline $\mathrm{P} 7$ & 413508 George West 2 SSW, George West, Tex. & $28^{\circ} 18^{\prime}--^{\prime \prime}$ & $98^{\circ} 07^{\prime}--^{\prime \prime}$ & $\mathrm{R}$ & $1961-2008$ & $410639,417836,410144$ \\
\hline P8 & 417836 Runge, Tex. & $28^{\circ} 53^{\prime}--^{\prime \prime}$ & $97^{\circ} 42^{\prime}--^{\prime \prime}$ & $\mathrm{R}$ & $1961-2008$ & $410639,413508,413299$ \\
\hline P9 & 410639 Beeville 5 NE, Beeville, Tex. & $28^{\circ} 27^{\prime}--^{\prime \prime}$ & $97^{\circ} 42^{\prime}--^{\prime \prime}$ & $\mathrm{R}, \mathrm{T}$ & $1961-2008$ & $413508,417836,410144$ \\
\hline P10 & 410144 Alice, Tex. & $27^{\circ} 44^{\prime}--"$ & $98^{\circ} 04^{\prime}--^{\prime \prime}$ & $\mathrm{R}, \mathrm{T}$ & $1961-2008$ & $413508,414058,410639$ \\
\hline $\mathrm{P} 11$ & 414058 Hebbronville, Tex. & $27^{\circ} 19^{\prime}--^{\prime \prime}$ & $98^{\circ} 41^{\prime}--^{\prime \prime}$ & $\mathrm{R}$ & $1961-2008$ & $410144,413508,413299$ \\
\hline $\mathrm{T} 1$ & 412906 Encinal, Tex. & $28^{\circ} 01^{\prime}--{ }^{\prime \prime}$ & $99^{\circ} 21^{\prime}--^{\prime \prime}$ & $\mathrm{T}$ & $1961-2008$ & $410639,414920,412458$ \\
\hline
\end{tabular}

an integrated basin-scale software package that combines watershed processes with in-stream fate and transport in onedimensional characterization of stream channels, and it can simulate a wide variety of stream and watershed conditions with reasonable accuracy (Donigian and others, 1995).

HSPF has been used previously in south Texas to represent complex hydrologic systems, simulate streamflow, and estimate groundwater recharge (Ockerman, 2002, 2005, 2007; Ockerman and McNamara, 2003; Ockerman and Roussel, 2009; Lizárraga and Ockerman, 2010, 2011).

\section{Model Configuration}

A functional description of the HSPF model used in this study is provided in Lizárraga and Ockerman (2011) and depicted here in schematic form (fig. 4). The middle Nueces River watershed model was developed by (1) defining stream and reservoir reaches (RCHRESs) and their associated drainage areas, called catchments; (2) defining pervious land segments (PERLNDs) on the basis of land cover and locations of rain gages and determining their acreages within each RCHRES drainage area; (3) developing the input time series of meteorological and streamflow data; and (4) determining initial values of associated model parameters. Initial estimates of parameter values were determined or estimated from default values, previous watershed studies in south Texas (Ockerman, 2007; Lizárraga and Ockerman, 2010, 2011), and available evapotranspiration, rainfall, and streamflow data.

\section{Subwatershed and Stream Reach Delineations}

Because of the large size of the study area, the middle Nueces watershed was divided into eight subwatersheds, and a separate model for each subwatershed was developed (fig. 5, table 4). Each subwatershed model consisted of RCHRESs and PERLNDs. USGS 7.5-minute digital elevation models (U.S. Geological Survey, 2001) were used to delineate the RCHRES drainage areas and to calculate topographic information. Channel characteristics for each RCHRES were entered into HSPF function tables (FTABLES) to establish channel shape-streamflow relations. For gaged stream reaches, these FTABLE parameters describing the volume of water within each RCHRES (cross-sectional area multiplied by the length of the RCHRES) were based on streamflow measurements (cross-sectional area and streamflow) made at USGS streamflow-gaging stations. The FTABLE parameters for ungaged reaches were estimated on the basis of volumedischarge relations from nearby RCHRESs that used 
Table 2. Annual rainfall at selected National Weather Service meteorological stations in the middle Nueces River watershed, south Texas, 1961-2008.

[Rainfall amounts are given in inches]

\begin{tabular}{|c|c|c|c|c|c|c|c|c|c|c|c|}
\hline \multirow[b]{2}{*}{ Year or period } & \multicolumn{11}{|c|}{ National Weather Service station number and site identifier (table 1, fig. 3) } \\
\hline & $\begin{array}{c}412679 \\
\text { (site P1) }\end{array}$ & $\begin{array}{c}414920 \\
\text { (site P2) }\end{array}$ & $\begin{array}{c}411486 \\
\text { (site P3) }\end{array}$ & $\begin{array}{c}412048 \\
\text { (site P4) }\end{array}$ & $\begin{array}{c}412458 \\
\text { (site P5) }\end{array}$ & $\begin{array}{c}413299 \\
\text { (site P6) }\end{array}$ & $\begin{array}{c}413508 \\
\text { (site P7) }\end{array}$ & $\begin{array}{c}417836 \\
\text { (site P8) }\end{array}$ & $\begin{array}{c}410639 \\
\text { (site P9) }\end{array}$ & $\begin{array}{c}410144 \\
\text { (site P10) }\end{array}$ & $\begin{array}{c}414058 \\
\text { (site P11) }\end{array}$ \\
\hline 1962 & 11.1 & 14.2 & 10.3 & 13.7 & 17.0 & 13.0 & 20.8 & 26.7 & 20.8 & 19.3 & 17.8 \\
\hline 1963 & 16.1 & 14.7 & 19.5 & 19.3 & 19.3 & 20.1 & 20.5 & 18.1 & 20.5 & 16.5 & 15.0 \\
\hline 1965 & 21.7 & 21.6 & 21.8 & 20.9 & 30.0 & 24.2 & 27.5 & 41.5 & 27.5 & 30.1 & 27.1 \\
\hline 1966 & 21.0 & 18.7 & 21.3 & 19.7 & 22.5 & 29.0 & 25.5 & 28.7 & 25.5 & 33.7 & 33.7 \\
\hline 1967 & 17.1 & 18.5 & 25.5 & 27.9 & 30.2 & 32.8 & 40.6 & 44.4 & 40.6 & 33.5 & 36.4 \\
\hline 1968 & 24.4 & 26.6 & 23.9 & 25.4 & 33.2 & 23.1 & 33.4 & 31.5 & 31.5 & 30.0 & 18.0 \\
\hline 1972 & 17.7 & 16.0 & 20.5 & 25.0 & 23.1 & 12.9 & 34.3 & 30.0 & 35.9 & 30.7 & 24.1 \\
\hline 1973 & 31.8 & 31.8 & 31.8 & 39.7 & 33.1 & 30.1 & 34.4 & 52.0 & 46.3 & 43.3 & 42.3 \\
\hline 1974 & 19.5 & 19.5 & 19.5 & 33.9 & 27.1 & 24.9 & 46.2 & 27.5 & 31.0 & 27.7 & 23.1 \\
\hline 1975 & 24.8 & 21.6 & 23.1 & 26.8 & 29.6 & 26.8 & 18.6 & 25.9 & 29.4 & 24.1 & 24.7 \\
\hline 1976 & 37.9 & 37.1 & 29.5 & 33.7 & 35.5 & 32.7 & 44.1 & 45.2 & 43.5 & 42.5 & 33.3 \\
\hline 1977 & 15.9 & 17.3 & 10.3 & 15.9 & 15.5 & 14.0 & 28.7 & 33.6 & 30.4 & 22.4 & 19.2 \\
\hline 1978 & 22.8 & 16.7 & 26.9 & 24.5 & 23.5 & 24.4 & 22.5 & 33.9 & 34.2 & 27.9 & 20.9 \\
\hline 1985 & 24.2 & 25.6 & 21.0 & 30.7 & 28.9 & 23.2 & 38.2 & 37.0 & 31.3 & 30.6 & 27.8 \\
\hline 1986 & 23.0 & 30.4 & 28.5 & 26.8 & 30.4 & 31.4 & 21.4 & 28.7 & 35.8 & 23.0 & 16.1 \\
\hline 1987 & 31.8 & 32.2 & 23.6 & 21.9 & 28.0 & 18.2 & 24.9 & 32.1 & 35.8 & 28.3 & 31.6 \\
\hline 1988 & 13.4 & 13.4 & 11.3 & 15.1 & 15.1 & 13.8 & 14.3 & 20.1 & 17.6 & 22.7 & 22.0 \\
\hline 1989 & 15.6 & 20.4 & 14.8 & 20.5 & 20.5 & 14.9 & 16.0 & 21.1 & 18.5 & 13.0 & 14.7 \\
\hline 1990 & 28.5 & 32.5 & 35.7 & 23.4 & 23.4 & 24.1 & 25.8 & 20.9 & 35.5 & 23.0 & 18.6 \\
\hline 1991 & 25.6 & 21.8 & 23.0 & 21.8 & 24.9 & 22.2 & 35.3 & 40.3 & 35.4 & 34.7 & 30.0 \\
\hline 1992 & 32.9 & 30.5 & 25.8 & 25.0 & 31.5 & 27.0 & 32.3 & 32.9 & 48.1 & 30.9 & 33.2 \\
\hline 1993 & 13.9 & 17.3 & 12.5 & 13.8 & 17.8 & 14.8 & 22.3 & 24.0 & 37.5 & 29.0 & 26.2 \\
\hline 1994 & 18.5 & 27.2 & 26.8 & 23.7 & 24.9 & 30.0 & 27.7 & 39.5 & 36.0 & 29.6 & 17.7 \\
\hline 1995 & 17.1 & 21.8 & 17.3 & 22.6 & 18.0 & 23.0 & 18.6 & 22.9 & 20.5 & 25.9 & 42.7 \\
\hline 1996 & 11.7 & 13.4 & 10.0 & 20.5 & 12.3 & 13.1 & 16.2 & 24.7 & 21.8 & 13.8 & 11.5 \\
\hline 1997 & 21.3 & 23.9 & 25.5 & 28.8 & 32.8 & 29.1 & 37.5 & 39.6 & 40.5 & 27.6 & 23.9 \\
\hline
\end{tabular}


Table 2. Annual rainfall at selected National Weather Service meteorological stations in the middle Nueces River watershed, south Texas, 1961-2008.-Continued

[Rainfall amounts are given in inches]

\begin{tabular}{|c|c|c|c|c|c|c|c|c|c|c|c|}
\hline \multirow[b]{2}{*}{ Year or period } & \multicolumn{11}{|c|}{ National Weather Service station number and site identifier (table 1, fig. 3) } \\
\hline & $\begin{array}{c}412679 \\
\text { (site P1) }\end{array}$ & $\begin{array}{c}414920 \\
\text { (site P2) }\end{array}$ & $\begin{array}{c}411486 \\
\text { (site P3) }\end{array}$ & $\begin{array}{c}412048 \\
\text { (site P4) }\end{array}$ & $\begin{array}{c}412458 \\
\text { (site P5) }\end{array}$ & $\begin{array}{c}413299 \\
\text { (site P6) }\end{array}$ & $\begin{array}{c}413508 \\
\text { (site P7) }\end{array}$ & $\begin{array}{c}417836 \\
\text { (site P8) }\end{array}$ & $\begin{array}{c}410639 \\
\text { (site P9) }\end{array}$ & $\begin{array}{c}410144 \\
\text { (site P10) }\end{array}$ & $\begin{array}{c}414058 \\
\text { (site P11) }\end{array}$ \\
\hline 1999 & 20.1 & 23.5 & 18.0 & 18.3 & 20.1 & 17.0 & 21.2 & 15.7 & 23.5 & 23.9 & 15.8 \\
\hline 2000 & 16.6 & 18.8 & 14.7 & 19.9 & 19.9 & 24.9 & 25.8 & 35.3 & 31.6 & 18.1 & 13.3 \\
\hline 2002 & 16.4 & 36.3 & 21.9 & 48.1 & 48.1 & 49.4 & 39.5 & 40.9 & 35.9 & 20.1 & 21.0 \\
\hline 2003 & 28.6 & 34.0 & 26.8 & 28.7 & 29.6 & 35.2 & 27.6 & 32.9 & 34.1 & 32.3 & 33.6 \\
\hline 2004 & 39.9 & 36.5 & 24.9 & 35.4 & 42.6 & 42.7 & 33.1 & 44.6 & 48.9 & 29.8 & 24.3 \\
\hline 2005 & 14.9 & 15.7 & 9.90 & 13.6 & 20.1 & 16.5 & 19.7 & 32.7 & 31.7 & 20.3 & 15.5 \\
\hline 1961-2008 annual mean & 21.0 & 22.4 & 21.0 & 23.4 & 24.9 & 23.7 & 28.0 & 31.5 & 32.2 & 27.8 & 23.5 \\
\hline 1961-2008 standard deviation & 7.35 & 6.75 & 7.38 & 8.32 & 8.59 & 8.44 & 8.97 & 8.65 & 8.90 & 7.73 & 7.90 \\
\hline 2000-8 annual mean & 20.6 & 24.3 & 18.8 & 26.3 & 25.7 & 30.4 & 30.5 & 35.1 & 35.3 & 28.4 & 23.3 \\
\hline $2000-8$ standard deviation & 10.2 & 9.76 & 7.55 & 12.1 & 14.9 & 13.3 & 10.2 & 9.60 & 9.42 & 10.2 & 7.50 \\
\hline 1990-99 annual mean & 20.3 & 23.4 & 21.7 & 22.3 & 24.0 & 22.8 & 26.2 & 29.9 & 33.5 & 26.9 & 24.2 \\
\hline 1990-99 standard deviation & 6.91 & 5.70 & 7.52 & 4.07 & 7.18 & 6.00 & 7.06 & 9.29 & 8.88 & 5.80 & 9.27 \\
\hline
\end{tabular}

Table 3. U.S. Geological Survey stations where data were obtained for the Hydrological Simulation Program—FORTRAN model of the middle Nueces River watershed, south Texas.

[USGS, U.S. Geologcal Survey; mi² $^{2}$, square miles; dd, degrees; mm, minutes; ss, seconds; --, not applicable]

\begin{tabular}{|c|c|c|c|c|c|c|c|}
\hline $\begin{array}{c}\text { Site } \\
\text { identifier } \\
\text { (fig. 3) }\end{array}$ & $\begin{array}{l}\text { USGS station } \\
\text { number }\end{array}$ & USGS station name & $\begin{array}{c}\text { Drainage } \\
\text { area } \\
\left(\mathrm{mi}^{2}\right)\end{array}$ & $\begin{array}{l}\text { Latitude } \\
\text { (ddmmss) }\end{array}$ & $\begin{array}{l}\text { Longitude } \\
\text { (ddmmss) }\end{array}$ & $\begin{array}{l}\text { Type } \\
\text { of data }\end{array}$ & $\begin{array}{l}\text { Period of } \\
\text { record } \\
\text { used }\end{array}$ \\
\hline Q2 & 08193000 & Nueces River near Asherton, Tex. & 4,082 & $28^{\circ} 30^{\prime} 00^{\prime \prime}$ & $99^{\circ} 40^{\prime} 54^{\prime \prime}$ & Streamflow & 1961-2008 \\
\hline Q3 & 08194000 & Nueces River at Cotulla, Tex. & 5,171 & $28^{\circ} 25^{\prime} 34^{\prime \prime}$ & $99^{\circ} 14^{\prime} 23^{\prime \prime}$ & Streamflow & 1961-2008 \\
\hline Q5 & 08194500 & Nueces River near Tilden, Tex. & 8,093 & $28^{\circ} 18^{\prime} 31^{\prime \prime}$ & $98^{\circ} 33^{\prime} 25^{\prime \prime}$ & Streamflow & $1961-2008$ \\
\hline Q6 & 08210000 & Nueces River near Three Rivers, Tex. & 15,427 & $28^{\circ} 25^{\prime} 38^{\prime \prime}$ & $98^{\circ} 10^{\prime} 40^{\prime \prime}$ & Streamflow & 1961-2008 \\
\hline Q7 & 08210400 & Lagarto Creek near George West, Tex. & 155 & $28^{\circ} 03^{\prime} 34^{\prime \prime}$ & $98^{\circ} 05^{\prime} 48^{\prime \prime}$ & Streamflow & 1971-2008 \\
\hline Q8 & 08210500 & Lake Corpus Christi near Mathis, Tex. & 16,502 & $28^{\circ} 02^{\prime} 17^{\prime \prime}$ & $97^{\circ} 52^{\prime} 15^{\prime \prime}$ & $\begin{array}{l}\text { Reservoir } \\
\text { elevation and } \\
\text { storage }\end{array}$ & 1961-2008 \\
\hline ET1 & 290810099212100 & $\begin{array}{l}\text { SW Medina County meteorological } \\
\text { station near D'Hanis, Tex. }\end{array}$ & -- & $29^{\circ} 08^{\prime} 10.3^{\prime \prime}$ & $99^{\circ} 21^{\prime} 20.5^{\prime \prime}$ & $\begin{array}{l}\text { Evapotranspira- } \\
\text { tion }\end{array}$ & 2006-2008 \\
\hline
\end{tabular}




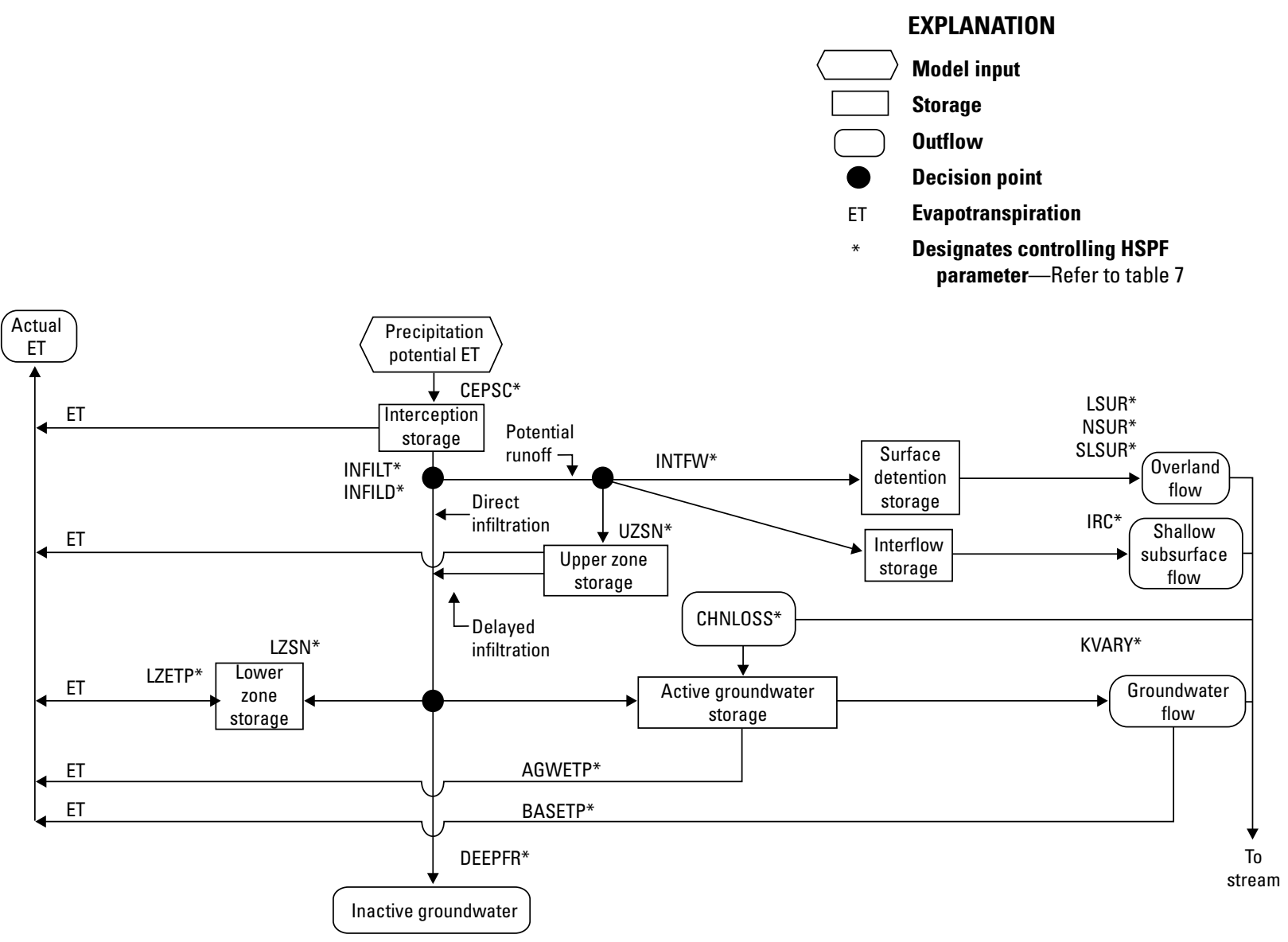

Figure 4. Hydrological Simulation Program—FORTRAN (HSPF) flowchart for hydrologic processes for pervious land segments (modified from Berris, 1995, p. 14).

streamflow-gaging station data. The eight subwatersheds, their contributing drainage areas, and the Carrizo-Wilcox aquifer outcrop areas within each subwatershed are listed in table 4.

For the Mathis subwatershed (fig. 6, table 4), the main body of Lake Corpus Christi was represented as one reach (RCHRES 132) with FTABLE values determined on the basis of volumetric surveys (Texas Water Development Board, 2003). RCHRES 132 was modeled as 11 miles (mi.) long and 2 mi. wide. Reservoir water-level elevations, measured at USGS surface-water monitoring station 08210500 Lake Corpus Christi near Mathis, Tex. (fig. 6, table 3, site Q8), were used to calibrate the reservoir volume, and releases were modeled as direct withdrawals from RCHRES 132. Monthly evaporation estimates from 2001 to 2008 (Nueces River Authority, 2011) also were used for model calibration.

\section{Classification of Pervious Land Segments and Variation of Model Parameters}

Spatial information was compiled and analyzed by using the geographical information system software ArcGIS
(ESRI, 2009). The pervious acreage of each PERLND was determined by using the 2001 land-cover data from the U.S. Environmental Protection Agency's Multi-Resolution Land Characteristics Consortium (Homer and others, 2004; MultiResolution Land Characteristics Consortium, 2010). Because impervious land in the study area composed a small fraction of the total study area, all land categories were classified as pervious; the hydrologic effects of impervious areas within PERLNDs are accounted for indirectly through the parameter calibration process. Areas categorized as open water were modeled as RCHRES surface areas. The RCHRES surface area varies during model simulation on the basis of streamflow and channel dimensions in the FTABLEs.

Approximately $464 \mathrm{mi}^{2}$ of the Carrizo-Wilcox aquifer outcrop area, as defined by the Texas Water Development Board (Ashworth and Hopkins, 1995), is within the study area (fig. 1). ArcGIS was used to intersect the Carrizo-Wilcox aquifer outcrop area geodatabase with the pervious acreage so that the middle Nueces River watershed model could be used to generate output for the Carrizo-Wilcox aquifer outcrop area within each subwatershed model (table 4). 


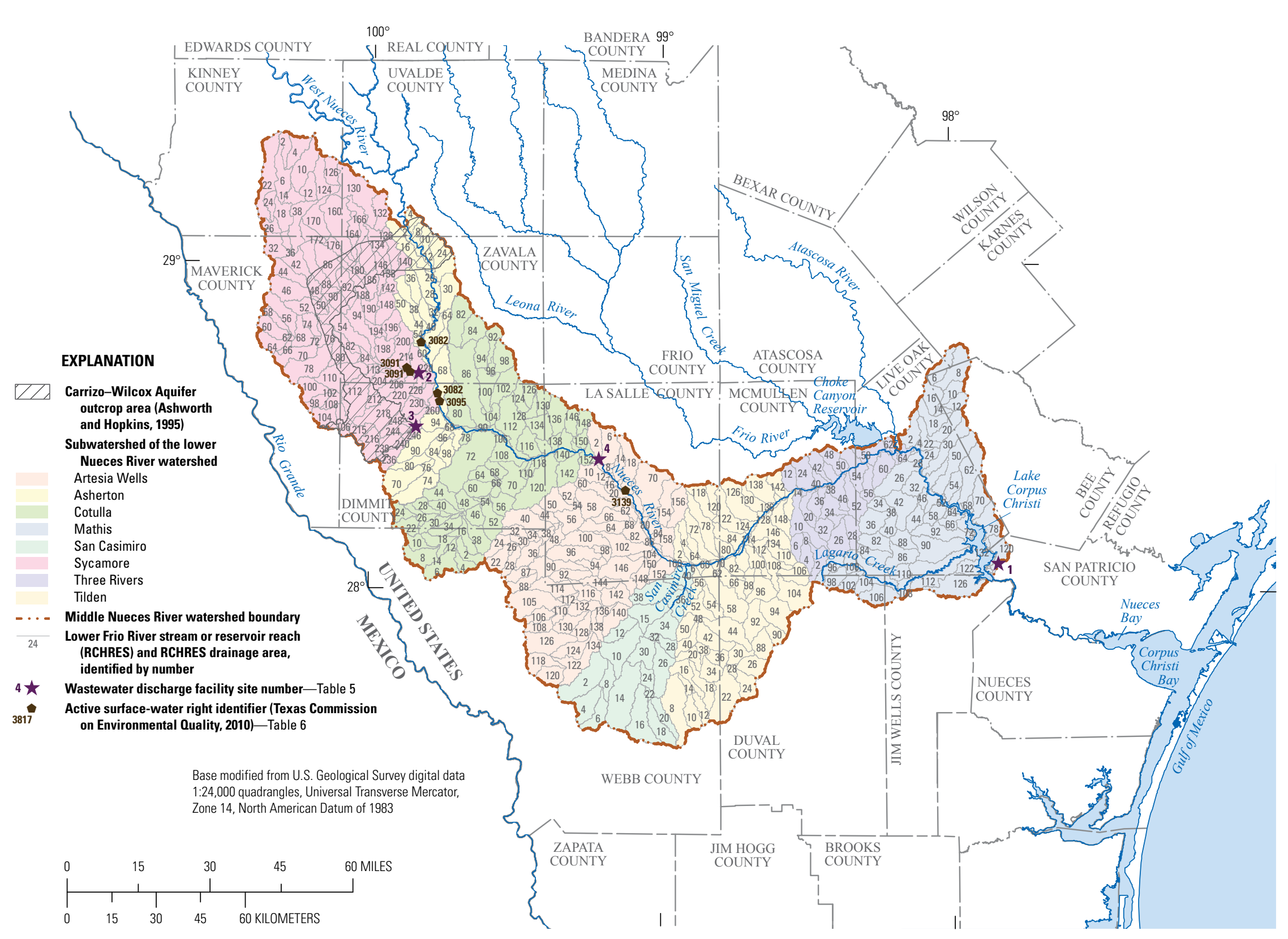

Figure 5. Subwatershed and stream and reservoir reach delineation for the Hydrological Simulation Program—FORTRAN model of the middle Nueces River watershed, south Texas. 
Table 4. Subwatersheds of the Hydrological Simulation Program-FORTRAN model of the middle Nueces River watershed, south Texas. [mi², square miles; USGS, U.S. Geological Survey; --, not applicable]

\begin{tabular}{|c|c|c|c|c|}
\hline $\begin{array}{l}\text { Subwatershed } \\
\text { number }\end{array}$ & $\begin{array}{l}\text { Subwatershed } \\
\text { name }\end{array}$ & Subwatershed description & $\begin{array}{l}\text { Drainage } \\
\text { area } \\
\left(\mathrm{mi}^{2}\right)\end{array}$ & $\begin{array}{l}\text { Carrizo-Wilcox } \\
\text { aquifer outcrop area } \\
\left(\mathbf{m i}^{2}\right)\end{array}$ \\
\hline 1 & Artesia Wells & $\begin{array}{l}\text { Nueces River downstream from the outlet of the Cotulla model to the } \\
\text { confluence of the Nueces River and San Casimiro Creek }\end{array}$ & 1,266 & -- \\
\hline 2 & Asherton & $\begin{array}{l}\text { Nueces River downstream from the USGS streamflow-gaging station } \\
08192000 \text { Nueces River below Uvalde (fig. 3, table 3, site Q1) to } \\
\text { the USGS streamflow-gaging station } 08193000 \text { Nueces River near } \\
\text { Asherton (fig. 3, table 3, site Q2) }\end{array}$ & 503 & 83 \\
\hline 3 & Cotulla & $\begin{array}{l}\text { Nueces River downstream from the outlet of the Asherton model to near } \\
\text { the USGS streamflow-gaging station } 08194000 \text { Nueces River at Cotulla } \\
\text { (fig. 3, table 3, site Q3) }\end{array}$ & 1,143 & -- \\
\hline 4 & Mathis & $\begin{array}{l}\text { Nueces River downstream from the outlet of the Three Rivers model to } \\
\text { the outlet of Lake Corpus Christi }\end{array}$ & 1,064 & -- \\
\hline 5 & San Casimiro & $\begin{array}{l}\text { San Casimiro Creek from its headwaters to its confluence with the } \\
\text { Nueces River }\end{array}$ & 547 & -- \\
\hline 6 & Sycamore & $\begin{array}{l}\text { Sycamore Creek and other tributaries west of Crystal City from their } \\
\text { headwaters to the confluence with the Nueces River near Crystal City }\end{array}$ & 1,669 & 381 \\
\hline 7 & Three Rivers & $\begin{array}{l}\text { Nueces River downstream from the outlet of the Tilden model to the } \\
\text { USGS streamflow-gaging station } 08210000 \text { Nueces River near Three } \\
\text { Rivers (fig. 3, table 3, site Q6) }\end{array}$ & 417 & -- \\
\hline 8 & Tilden & $\begin{array}{l}\text { Nueces River downstream from its confluence with San Casimiro Creek } \\
\text { to the USGS streamflow-gaging station } 08194500 \text { Nueces River near } \\
\text { Tilden (fig. 3, table 3, site Q5) }\end{array}$ & 1,117 & -- \\
\hline
\end{tabular}

County soil geodatabases from the Natural Resources Conservation Service (2010) were compiled for the study area (fig. 7) if available. Relative soil infiltration rates, as defined by the Natural Resources Conservation Service (2010), aided in the selection and gradation of initial and final estimates for PERLND parameters, such as the index to infiltration capacity of the soil (INFILT).

The Thiessen method (Linsley and others, 1982) was used to delineate rainfall areas (fig. 8) based on the locations of the 11 NWS meteorological stations (fig. 3, table 1). The Thiessen rainfall areas were used to apply the associated rainfall time-series data to the corresponding PERLNDs. Similarly, meteorological data from the five NWS meteorological stations in the study area that record temperature (fig. 3, table 1; sites P1, P5, P9, P10, and T1) were assigned to represent different areas for the computation of potential evapotranspiration rates. By using the Hamon method (Bidlake, 2002) integrated within BASINS 4.0 (U.S. Environmental Protection Agency, 2007), potential evapotranspiration rates were estimated from a relation between rainfall, wind speed, cloud cover, solar radiation, air temperature, and dew point temperature.
For the Mathis subwatershed model, the difference between the measured and simulated reservoir volume in Lake Corpus Christi was minimized by using the inverse distance method (Smith, 1992) for converting measured point rainfall into a spatial distribution of rainfall rather than the Thiessen method. The differences between computed (water surface elevation is measured and streamflow is computed based on a water surface elevation-streamflow relation) and simulated streamflow were satisfactory in the other subwatersheds using the Thiessen method, but not satisfactory in the reservoir-dominated Mathis subwatershed (discussed in the "Model Calibration and Model Testing" section). This improvement resulted from a more accurate representation of rainfall in the Mathis subwatershed during the calibration period achieved by using multiple weighted data sources as opposed to the nearest meteorological station provided by the Thiessen method. Using the inverse distance method, the distance from NWS meteorological stations to the centroid of the Mathis subwatershed was used to define a single rainfall time series for the Mathis subwatershed model. 


\section{EXPLANATION}

[..] Mathis subwatershed

$\overline{14}$ Lake Corpus Christi stream and reservoir reach (RCHRES) and associated drainage area, identified by number

07 U.S. Geological Survey streamflow-gaging station and site identifier-Table 3

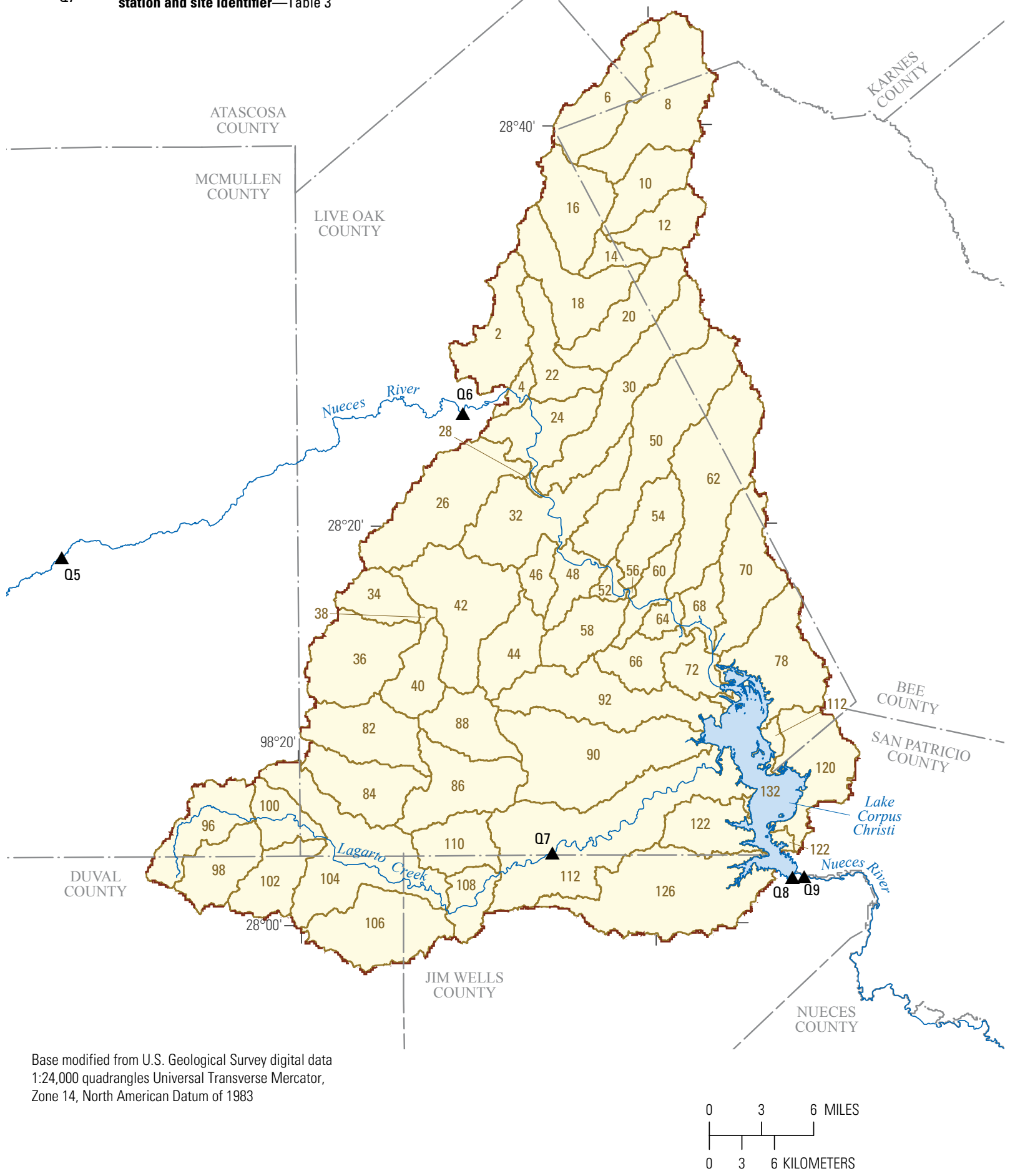

Figure 6. Streams or reservoir reaches and associated drainage areas for the Mathis subwatershed used in the Hydrological Simulation Program—FORTRAN model of the middle Nueces River watershed, south Texas. 


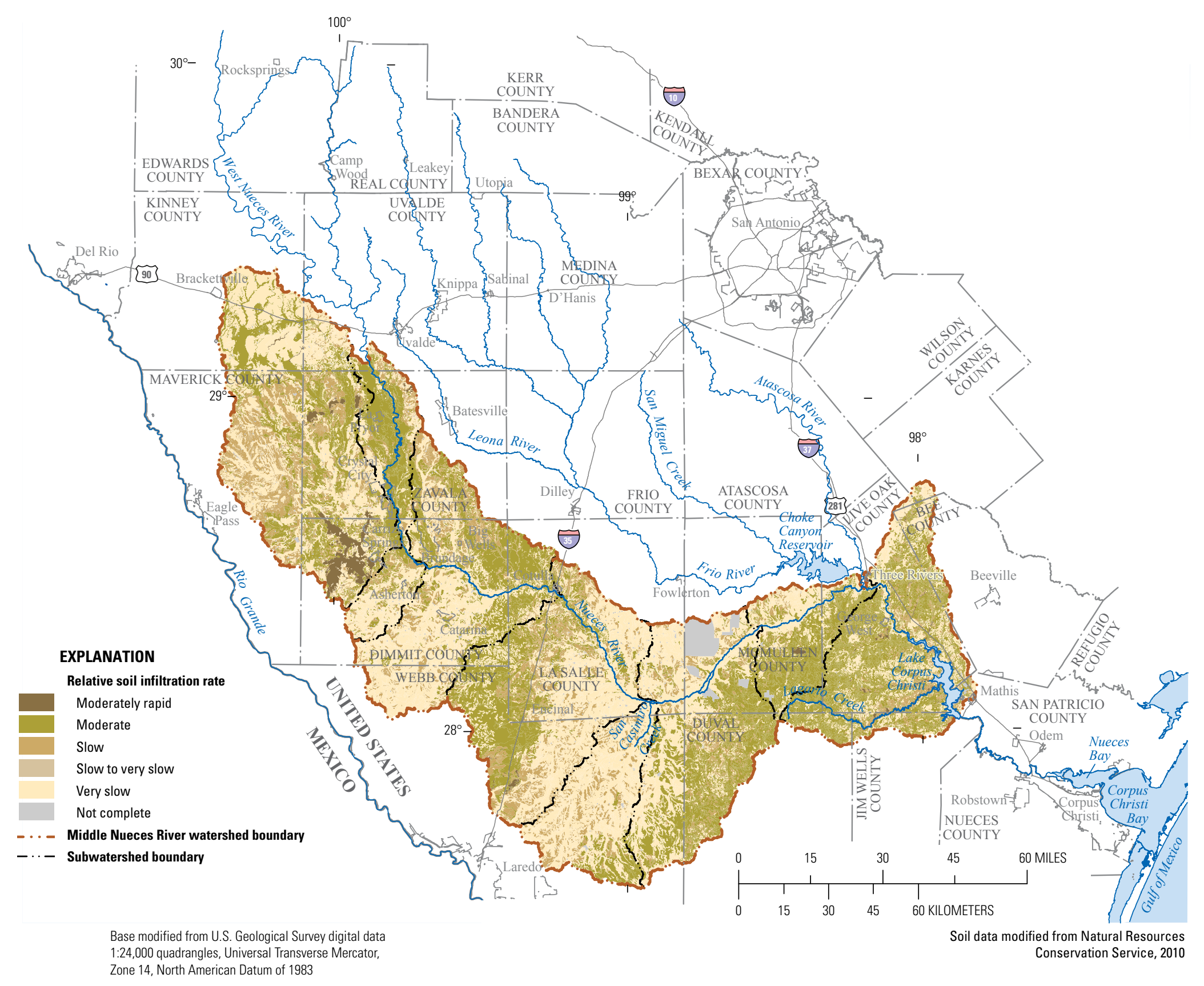

Figure 7. Relative soil infiltration rates in the middle Nueces River watershed, south Texas. 

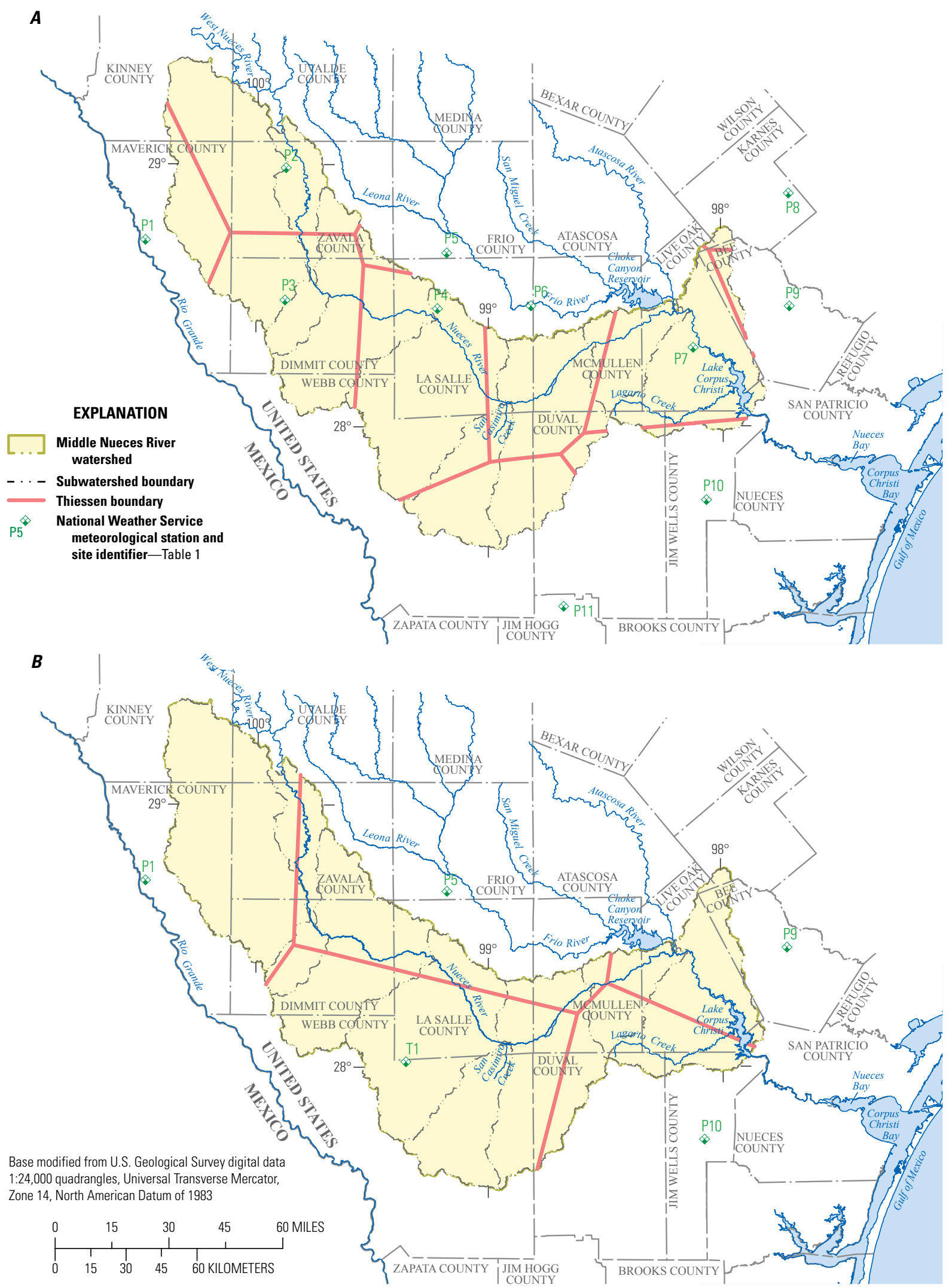

Figure 8. Locations of National Weather Service meteorological stations and associated Thiessen areas. A, Stations and Thiessen areas for application of rainfall rates in the Hydrological Simulation Program—FORTRAN model of the middle Nueces River watershed, south Texas. $B$, Stations and Thiessen areas for application of potential evapotranspiration rates in the Hydrological Simulation Program—FORTRAN model of the middle Nueces River watershed, south Texas. 
For modeling purposes, the drainage area associated with each RCHRES was composed of a single PERLND. The acreage within the drainage area of each RCHRES was considered to be a unique PERLND for the middle Nueces River watershed model development and calibration, and a unique set of model parameter values could be developed for each PERLND during model development and calibration. Differences in model parameter values across PERLNDs largely were introduced from differences in Carrizo-Wilcox aquifer outcrop area and relative soil infiltration rates.

\section{Time-Series Development}

Streamflow data, meteorological data, wastewaterdischarge information, and surface-water withdrawals were input to the middle Nueces River watershed model as timeseries data as described in this section. Streamflow data from USGS stations within the study area were used for calibration (2000-8) and testing (1990-99) and also were used as inputs to the model at the upstream boundary. These time-series data were compiled from national databases and local agencies using the BASINS 4.0 (U.S. Environmental Protection Agency, 2007) download features (or by manually downloading the data) and were stored with an associated dataset number (DSN) in the watershed data management (WDM) file. Computed streamflow at USGS streamflowgaging station 08192000 Nueces River below Uvalde, Tex., was directly added to the upstream reach of the Asherton subwatershed model, and simulated streamflow from an HSPF model developed for the Lower Frio River watershed (fig. 1; Lizárraga and Ockerman, 2011) was added at the confluence of the Frio River and the Nueces River to account for flows from Choke Canyon Reservoir and the Atascosa River.

The model testing period for the reservoir volume of Lake Corpus Christi in the Mathis subwatershed model was July 15, 1992 through 2000, which was different from the streamflow testing period of 1990 through 1999. The testing period for the reservoir volume was chosen in order to start the testing period when the reservoir was full. Model calibration was $2000-8$ for streamflow and $2001-8$ for reservoir volume (2001 had better initial conditions for model initiation of reservoir volume).

BASINS 4.0 was used to download and process meteorological data measured at NWS sites (table 1) into hourly time series of potential evaporation rates by using the Hamon method (Bidlake, 2002). HSPF simulations were run by using an hourly time step. The algorithms in BASINS 4.0 (U.S. Environmental Protection Agency, 2007) were used to download and process national datasets through 2006. To extend the calibration record through 2008 for the middle Nueces River watershed model, available meteorological data for 2007-8 from the same or nearby NWS meteorological stations were obtained from the National Climatic Data Center (2009). The priority of nearby stations used to fill missing record for each station is shown in table 1 . These data were manually reviewed, processed, and appended to the hourly time series in the WDM files to apply the Hamon method in the same manner across all meteorological data. During simulations, HSPF used BASINS 4.0-computed potential evaporation estimates with other model input (precipitation, storage, lower zone parameters) to simulate actual evapotranspiration.

Mean daily wastewater-discharge estimates for four facilities in the study area (identified by using U.S. Environmental Protection Agency, 2004) were added to the relevant RCHRES for the entire simulation period, 1961-2008 (fig. 5; table 5). Surface-water withdrawals were simulated in all modeling time periods on the basis of annual active surface-water rights (permits) in the study area as of December 2010 exceeding 724 acre-feet per year $\left(1.0 \mathrm{ft}^{3} / \mathrm{s}\right)$ (table 6) (Texas Commission on Environmental Quality, 2010). Annual permitted irrigation withdrawal amounts (table 6) were disaggregated into time series of equal daily amounts withdrawn from April through September (the months when irrigation withdrawals are considered most likely). Nonirrigation uses were disaggregated into time series of equal daily amounts withdrawn throughout the year.

\section{Model Calibration and Model Testing}

Model calibration is an inherently iterative process of parameter evaluation and adjustment. Initial estimates of model parameters are adjusted until the simulated streamflow and evapotranspiration data compare favorably to gaged data and predefined calibration criteria are satisfied. Various acceptance criteria are used. Graphs and descriptive statistics facilitate comparisons between simulated and gaged data. Model testing involves using a calibrated model to simulate data for a time period different from the one used for calibration; simulated data are compared with additional gaged data that are not used in the initial calibration.

The parameters for the middle Nueces River watershed model were manually adjusted to meet acceptance criteria (Bicknell and others, 2001) for streamflow at various USGS streamflow-gaging stations in the watershed. Effort also was made to vary the model parameters in a consistent way across the subwatershed models. Calibrated values for selected parameters are listed by subwatershed in table 7 .

\section{Streamflow and Reservoir Volume}

A primary goal of hydrologic model calibration is to adjust model-simulated streamflow to match streamflow gaged at a nearby streamflow-gaging station. The middle Nueces River watershed model was calibrated in accordance with guidelines by Donigian and others (1984). These guidelines involved comparing gaged and simulated streamflow data and minimizing the difference between the total volumes of streamflow, the highest 10 percent of streamflows, and 
Table 5. Wastewater discharges included in the Hydrological Simulation Program—FORTRAN model of the middle Nueces River watershed, south Texas.

[HSPF, Hydrological Simulation Program-FORTRAN; RCHRES, stream and reservoir reach; acre-ft/yr, acre-feet per year]

\begin{tabular}{cllcc}
\hline $\begin{array}{c}\text { Facility } \\
\text { site } \\
\text { identifier }\end{array}$ & \multicolumn{1}{c}{$\begin{array}{c}\text { Facility } \\
\text { name }\end{array}$} & $\begin{array}{c}\text { Subwater- } \\
\text { shed }\end{array}$ & $\begin{array}{c}\text { Receiving } \\
\text { HSPF } \\
\text { RCHRES }\end{array}$ & $\begin{array}{c}\text { Average } \\
\text { discharge } \\
\text { (acre-ft/yr) }\end{array}$ \\
\hline 1 & Mathis & Mathis & 78 & 728 \\
2 & Crystal City & Sycamore & 224 & 1,100 \\
3 & Carrizo Springs & Sycamore & 246 & 538 \\
4 & Cotulla & Artesia Wells & 2 & 515 \\
\hline
\end{tabular}

${ }^{1}$ Average discharge amounts are from the U.S. Environmental Protection Agency (2004) for facilities discharging more than 724 acre-ft/yr (1 cubic foot per second).

the lowest 50 percent of streamflows. In addition, model-fit statistics generated by the software program GenScn version 2.3 build 10 (U.S. Environmental Protection Agency, 2007) were used to examine the quality of the model fit on an annual, monthly, weekly, and daily basis. Model-fit statistics included the (1) coefficient of determination $\left(\mathrm{R}^{2}\right)$ of the linear regression between computed and simulated streamflow; (2) model-fit efficiency, which is measured by the NashSutcliffe model-fit efficiency coefficient (NS) (Nash and Sutcliffe, 1970); (3) mean absolute error (MAE); and (4) root mean square error (RMSE). The $\mathrm{R}^{2}$ and NS are similar; each provides a measure of the variability in a dataset accounted for by the statistical model, in which a value of 1 indicates a perfect fit between computed and simulated values. The NS, however, provides a generally preferable evaluation of the fit quality because it measures the magnitude of the differences between computed and simulated values, whereas the $\mathrm{R}^{2}$ measures the difference between mean values (Zarriello and Ries, 2000). The MAE and RMSE statistics describe the difference between computed and simulated streamflow in original units $\left(\mathrm{ft}^{3} / \mathrm{s}\right)$.

The streamflow calibration process began with the most upstream subwatersheds by using available streamflow-gaging station data to adjust the middle Nueces River watershed model parameters. For example, data from USGS streamflowgaging station 08193000 Nueces River near Asherton, Tex. (fig. 3, table 3, site Q2), were used to calibrate streamflow for the drainage area upstream from the station in the Asherton and Sycamore subwatershed models. After calibration at USGS streamflow-gaging station 08193000 Nueces River near Asherton, Tex., the computed (1961-2008) flows at the station were routed along with other simulated flows generated from the outlets of RCHRESs 1-152 of the Cotulla subwatershed
Table 6. Active water rights (2010) included in the Hydrological Simulation Program-FORTRAN model of the middle Nueces River watershed, south Texas.

[HSPF, Hydrological Simulation Program-FORTRAN; RCHRES, stream and reservoir reach; acre-ft/yr, acre-feet per year]

\begin{tabular}{clccl}
\hline $\begin{array}{c}\text { Water } \\
\text { rights } \\
\text { identifier }\end{array}$ & $\begin{array}{c}\text { Subwater- } \\
\text { shed }\end{array}$ & $\begin{array}{c}\text { HSPF } \\
\text { RCHRES }\end{array}$ & $\begin{array}{c}\text { Annual } \\
\text { amount } \\
\text { (acre-ft/yr) }\end{array}$ & Use \\
\hline 3091 & Sycamore & 214 & 898 & Irrigation \\
3091 & Sycamore & 214 & 800 & Irrigation \\
3082 & Asherton & 54 & 8,000 & Irrigation \\
3082 & Asherton & 68 & 20,000 & Irrigation \\
3095 & Asherton & 68 & 1,090 & Irrigation \\
3139 & Artesia Wells & 16 & 2,020 & Irrigation \\
\hline
\end{tabular}

${ }^{1}$ Water rights identifiers and amounts are from the Texas Commission on Environmental Quality (2010). Data are for water rights of more than 724 acre-ft/yr (1 cubic foot per second).

model to the next calibration point at USGS streamflowgaging station 08194000 Nueces River at Cotulla, Tex. (fig. 3, table 3, site Q3). Similarly, the Artesia Wells subwatershed model was calibrated to the computed flows for 1961-2002 at USGS streamflow-gaging station 08194000 Nueces River at Cotulla, Tex. By routing computed streamflow rather than simulated streamflow downstream wherever possible, simulation errors (differences between computed and simulated streamflows) were not propagated downstream. In some subwatersheds, there were no USGS streamflowgaging stations near the outlets of the subwatershed models. For example, the Artesia Wells subwatershed model does not have a USGS streamflow-gaging station near its outlet near the confluence of the Nueces River and San Casimiro Creek. The simulated flows from the Artesia Wells and San Casimiro subwatershed models were combined as a times series and used to define the boundary inflows to the Tilden subwatershed model. Model parameters in the Artesia Wells subwatershed model, the San Casimiro subwatershed model, and the Tilden subwatershed model were calibrated such that simulated flows at the outlet of the Tilden subwatershed model matched streamflow computed at USGS streamflow-gaging station 08194500 Nueces River near Tilden, Tex.

Data from four USGS streamflow-gaging stations (fig. 3, table 3, sites Q2, Q3, Q5, Q6) in the middle Nueces River watershed were used for both model calibration (2000-8 for streamflow and 2001-8 for reservoir volume) and model testing (1990-99 for streamflow and 1992-2000 for reservoir volume). Computed and simulated streamflows and modelfit statistics for the four USGS streamflow-gaging stations 
Table 7. Calibrated values for selected parameters, by subwatershed, for the Hydrological Simulation Program—FORTRAN model of the middle Nueces River watershed, south Texas.

\begin{tabular}{|c|c|c|c|c|c|c|c|c|c|c|}
\hline \multirow[b]{2}{*}{ Parameter } & \multirow[b]{2}{*}{ Description } & \multirow[b]{2}{*}{ Units } & \multicolumn{8}{|c|}{ Calibrated values by subwatershed } \\
\hline & & & Sycamore & Asherton & Cotulla & $\begin{array}{c}\text { Artesia } \\
\text { Wells }\end{array}$ & $\begin{array}{c}\text { San } \\
\text { Casimiro }\end{array}$ & Tilden & $\begin{array}{l}\text { Three } \\
\text { Rivers }\end{array}$ & Mathis \\
\hline AGWETP & $\begin{array}{l}\text { Fraction of remaining evapo- } \\
\text { transpiration from active } \\
\text { groundwater }\end{array}$ & None & 0.01 & 0.01 & 0.05 & 0.05 & 0.05 & 0.01 & 0.01 & 0.03 \\
\hline AGWRC & $\begin{array}{l}\text { Groundwater recession indexed } \\
\text { to rate of drainage }\end{array}$ & $1 /$ day & 0.92 & 0.92 & 0.92 & 0.92 & 0.96 & 0.92 & 0.92 & 0.95 \\
\hline BASETP & $\begin{array}{l}\text { Fraction of remaining evapo- } \\
\text { transpiration from base flow }\end{array}$ & None & 0.01 & 0.01 & 0.10 & 0.10 & 0.05 & 0.10 & 0.01 & 0.03 \\
\hline CEPSC & Interception storage capacity & Inches & 0.4 & 0.4 & 0.35 & 0.35 & 0.35 & 0.35 & 0.35 & 0.1 \\
\hline DEEPFR & $\begin{array}{l}\text { Fraction of groundwater inflow } \\
\text { to deep recharge }\end{array}$ & None & 0.7 & 0.7 & 0.3 & 0.5 & 0.9 & 0.5 & 0.95 & 0.5 \\
\hline INFILD & $\begin{array}{l}\text { Ratio of maximum to mean } \\
\text { infiltration rate of a pervious } \\
\text { area }\end{array}$ & None & 2.0 & 2.0 & 2.0 & 2.0 & 2.0 & 2.0 & 2.0 & 2.0 \\
\hline INFILT & $\begin{array}{l}\text { Index to infiltration capacity } \\
\text { of soil }\end{array}$ & $\begin{array}{r}\text { Inches/ } \\
\text { hour }\end{array}$ & 0.8 & 0.7 & 0.5 & 0.2 & 0.2 & 0.2 & 0.9 & 0.25 \\
\hline INTFW & Interflow index & None & 3 & 3 & 3 & 3 & 3 & 2 & 8.5 & 2 \\
\hline IRC & Interflow recession coefficient & $1 /$ day & 0.54 & 0.54 & 0.54 & 0.54 & 0.54 & 0.54 & 0.54 & 0.7 \\
\hline KVARY & Variable groundwater recession & $1 /$ inch & 2 & 2 & 2 & 2 & 2 & 2 & 0 & 1 \\
\hline LSUR & $\begin{array}{l}\text { Length of assumed overland } \\
\text { flow plane }\end{array}$ & Feet & 450 & 450 & 350 & 350 & 350 & 350 & 350 & 350 \\
\hline LZETP & Lower zone evapotranspiration & None & $0.2-0.9$ & $0.2-0.9$ & $0.2-.9$ & 0.8 & $0.2-0.9$ & $0.2-0.9$ & $0.4-0.8$ & $0.2-0.8$ \\
\hline LZSN & Lower zone nominal storage & Inches & 4.5 & 4.5 & 8.0 & 13.0 & 5.0 & 13.0 & 15.0 & 8.0 \\
\hline NSUR & $\begin{array}{l}\text { Manning's } \mathrm{n} \text { for assumed } \\
\text { overland flow plane }\end{array}$ & None & 0.30 & 0.30 & 0.15 & 0.15 & 0.15 & 0.15 & 0.30 & 0.30 \\
\hline SLSUR & $\begin{array}{l}\text { Slope of assumed overland } \\
\text { flow plane }\end{array}$ & Feet & 0.01 & 0.01 & 0.01 & 0.01 & 0.03 & 0.01 & 0.01 & 0.03 \\
\hline UZSN & Upper zone nominal storage & Inches & 1.0 & 1.0 & 1.0 & 1.5 & 0.30 & 1.5 & 1.5 & 1.0 \\
\hline CHNLOSS & $\begin{array}{l}\text { Channel losses (range in annual } \\
\text { values during the 1961-2008 } \\
\text { simulation period) }\end{array}$ & $\begin{array}{l}\text { Cubic } \\
\text { feet per } \\
\text { second }\end{array}$ & 0 & 0 & 0 & 0 & 0 & 0 & $12.3-578$ & 0 \\
\hline
\end{tabular}

used in the calibration and testing processes are listed in table 8. Although all nine USGS streamflow-gaging stations were used for model configuration, only four (stations 08193000, 08194000, 08194500, and 08210000; sites Q2, Q3, Q5, and Q6) could be used in both model calibration and testing because they were not used to define the flow entering or leaving the subwatershed (subwatershed boundary conditions). Channel losses (including overbank flood losses) were based on the channel dimensions and relations between the streamflow volume and discharge established in the RCHRES FTABLES. These losses were adjusted for each RCHRES during the streamflow calibration. Channel losses (CHNLOSS) were routed to active groundwater storage within the model (fig. 4). Water in active groundwater storage may evapotranspire, return to the stream channel, or recharge the groundwater (Lizárraga and Ockerman, 2011). 
Table 8. Streamflow calibration and testing results for the Hydrological Simulation Program—FORTRAN model of the middle Nueces River watershed, south Texas.

[acre-ft, acre-feet; $\mathrm{ft}^{3} / \mathrm{s}$, cubic feet per second; --, not applicable; RMSE, root mean squared error]

08193000 Nueces River near Asherton, Texas

Calibration period $2000-8$

\begin{tabular}{|c|c|c|c|c|}
\hline $\begin{array}{c}\text { Comparison of } \\
\text { streamflow volumes }\end{array}$ & $\begin{array}{l}\text { Computed } \\
\text { streamflow }\end{array}$ & $\begin{array}{l}\text { Simulated } \\
\text { streamflow }\end{array}$ & $\begin{array}{c}\text { Error }^{1} \\
\text { (percent) }\end{array}$ & $\begin{array}{c}\text { Acceptance } \\
\text { criteria }^{2} \\
\text { (percent) }\end{array}$ \\
\hline Total flow volume, million acre-ft & 1.38 & 1.47 & 6.1 & 10 \\
\hline Mean flow rate $\left(\mathrm{ft}^{3} / \mathrm{s}\right)$ & 212 & 225 & 6.1 & 10 \\
\hline Total of highest 10 percent of daily flows, million acre- $\mathrm{ft}$ & 1.03 & 1.04 & 1.0 & 10 \\
\hline Model-fit statistics & Annual & Monthly & 7-day & Daily \\
\hline Number of years, months, days, or hours & 9 & 108 & 469 & 3,288 \\
\hline Root mean square error $\left(\mathrm{ft}^{3} / \mathrm{s}\right)$ & 89.0 & 254 & 451 & 674 \\
\hline RMSE as a percentage of the mean flow rate & -- & -- & 213 & 318 \\
\hline
\end{tabular}

Testing period 1990-99

\begin{tabular}{|c|c|c|c|c|}
\hline $\begin{array}{c}\text { Comparison of } \\
\text { streamflow volumes }\end{array}$ & $\begin{array}{c}\text { Computed } \\
\text { streamflow }\end{array}$ & $\begin{array}{c}\text { Simulated } \\
\text { streamflow }\end{array}$ & $\begin{array}{c}\text { Error }^{1} \\
\text { (percent) }\end{array}$ & $\begin{array}{c}\text { Acceptance } \\
\text { criteria }^{2} \\
\text { (percent) }\end{array}$ \\
\hline Total flow volume, million acre-ft & 1.49 & 1.85 & 23.8 & 10 \\
\hline Mean flow rate $\left(\mathrm{ft}^{3} / \mathrm{s}\right)$ & 206 & 255 & 23.8 & 10 \\
\hline Total of highest 10 percent of daily flows, million acre-ft & 1.13 & 1.42 & 25.7 & 10 \\
\hline Model-fit statistics & Annual & Monthly & 7-day & Daily \\
\hline Number of years, months, days, or hours & 10 & 120 & 521 & 3,652 \\
\hline Root mean square error $\left(\mathrm{ft}^{3} / \mathrm{s}\right)$ & 83.0 & 264 & 518 & 1,170 \\
\hline RMSE as a percentage of the mean flow rate & -- & -- & 251 & 568 \\
\hline
\end{tabular}


Table 8. Streamflow calibration and testing results for the Hydrological Simulation Program—FORTRAN model of the middle Nueces River watershed, south Texas. - Continued

[acre-ft, acre-feet; $\mathrm{ft}^{3} / \mathrm{s}$, cubic feet per second; --, not applicable; RMSE, root mean squared error]

08193000 Nueces River near Asherton, Texas—Continued

Simulation period 1961-2008

\begin{tabular}{|c|c|c|c|c|}
\hline $\begin{array}{c}\text { Comparison of } \\
\text { streamflow volumes }\end{array}$ & $\begin{array}{l}\text { Computed } \\
\text { streamflow }\end{array}$ & $\begin{array}{c}\text { Simulated } \\
\text { streamflow }\end{array}$ & $\begin{array}{c}\text { Error }_{1} \\
\text { (percent) }\end{array}$ & $\begin{array}{c}\text { Acceptance } \\
\text { criteria }^{2} \\
\text { (percent) }\end{array}$ \\
\hline Total flow volume, million acre- $\mathrm{ft}$ & 6.78 & 7.62 & 12.3 & 10 \\
\hline Mean flow rate $\left(\mathrm{ft}^{3} / \mathrm{s}\right)$ & 195 & 219 & 12.3 & 10 \\
\hline Total of highest 10 percent of daily flows, million acre-ft & 5.49 & 5.72 & 4.20 & 10 \\
\hline Total of lowest 50 percent of daily flows, acre-ft & 1,600 & 136,000 & 8,420 & 10 \\
\hline Model-fit statistics & Annual & Monthly & 7-day & Daily \\
\hline Number of years, months, days, or hours & 48 & 576 & 2,504 & 17,532 \\
\hline Coefficient of determination $\left(\mathrm{R}^{2}\right)$ & 0.85 & 0.79 & 0.68 & 0.45 \\
\hline Nash-Sutcliffe model-fit efficiency coefficient (NS) & 0.84 & 0.78 & 0.67 & 0.43 \\
\hline Mean absolute error $\left(\mathrm{ft}^{3} / \mathrm{s}\right)$ & 57.0 & 99.0 & 121 & 140 \\
\hline Root mean square error $\left(\mathrm{ft}^{3} / \mathrm{s}\right)$ & 79.0 & 251 & 483 & 820 \\
\hline RMSE as a percentage of the mean flow rate & -- & -- & 248 & 421 \\
\hline
\end{tabular}

08194000 Nueces River near Cotulla, Texas

Calibration period 2000-8

\begin{tabular}{|c|c|c|c|c|}
\hline $\begin{array}{c}\text { Comparison of } \\
\text { streamflow volumes }\end{array}$ & $\begin{array}{l}\text { Computed } \\
\text { streamflow }\end{array}$ & $\begin{array}{l}\text { Simulated } \\
\text { streamflow }\end{array}$ & $\begin{array}{c}\text { Error }^{1} \\
\text { (percent) }\end{array}$ & $\begin{array}{c}\text { Acceptance } \\
\text { criteria }^{2} \\
\text { (percent) }\end{array}$ \\
\hline Total flow volume, million acre-ft & 1.60 & 1.83 & 14 & 10 \\
\hline Mean flow rate $\left(\mathrm{ft}^{3} / \mathrm{s}\right)$ & 245 & 280 & 14 & 10 \\
\hline Total of highest 10 percent of daily flows, million acre- $\mathrm{ft}$ & 1.24 & 1.37 & 11 & 10 \\
\hline Model-fit statistics & Annual & Monthly & 7-day & Daily \\
\hline Number of years, months, days, or hours & 9 & 108 & 469 & 3,288 \\
\hline Root mean square error $\left(\mathrm{ft}^{3} / \mathrm{s}\right)$ & 55.0 & 323 & 525 & 792 \\
\hline RMSE as a percentage of the mean flow rate & -- & -- & 214 & 323 \\
\hline
\end{tabular}


Table 8. Streamflow calibration and testing results for the Hydrological Simulation Program—FORTRAN model of the middle Nueces River watershed, south Texas.-Continued

[acre-ft, acre-feet; $\mathrm{ft}^{3} / \mathrm{s}$, cubic feet per second; --, not applicable; RMSE, root mean squared error]

08194000 Nueces River near Cotulla, Texas—Continued

Testing period 1990-99

\begin{tabular}{|c|c|c|c|c|}
\hline $\begin{array}{c}\text { Comparison of } \\
\text { streamflow volumes }\end{array}$ & $\begin{array}{l}\text { Computed } \\
\text { streamflow }\end{array}$ & $\begin{array}{l}\text { Simulated } \\
\text { streamflow }\end{array}$ & $\begin{array}{c}\text { Error }^{1} \\
\text { (percent) }\end{array}$ & $\begin{array}{c}\text { Acceptance } \\
\text { criteria }^{2} \\
\text { (percent) }\end{array}$ \\
\hline Total flow volume, million acre-ft & 1.47 & 1.62 & 10.3 & 10 \\
\hline Mean flow rate $\left(\mathrm{ft}^{3} / \mathrm{s}\right)$ & 203 & 224 & 10.3 & 10 \\
\hline Total of highest 10 percent of daily flows, million acre-ft & 1.11 & 1.22 & 9.90 & 10 \\
\hline Model-fit statistics & Annual & Monthly & 7-day & Daily \\
\hline Number of years, months, days, or hours & 10 & 120 & 521 & 3652 \\
\hline Coefficient of determination $\left(\mathrm{R}^{2}\right)$ & 0.97 & 0.85 & 0.67 & 0.47 \\
\hline Root mean square error $\left(\mathrm{ft}^{3} / \mathrm{s}\right)$ & 41.0 & 190 & 459 & 679 \\
\hline RMSE as a percentage of the mean flow rate & -- & -- & 226 & 334 \\
\hline
\end{tabular}

Simulation period 1961-2008

\begin{tabular}{|c|c|c|c|c|}
\hline Comparison of streamflow volumes & $\begin{array}{l}\text { Computed } \\
\text { streamflow }\end{array}$ & $\begin{array}{l}\text { Simulated } \\
\text { streamflow }\end{array}$ & $\begin{array}{c}\text { Error }^{1} \\
\text { (percent) }\end{array}$ & $\begin{array}{c}\text { Acceptance } \\
\text { criteria }^{2} \\
\text { (percent) }\end{array}$ \\
\hline Mean flow rate $\left(\mathrm{ft}^{3} / \mathrm{s}\right)$ & 235 & 245 & 4.30 & 10 \\
\hline Total of highest 10 percent of daily flows, million acre-ft & 6.75 & 6.80 & 0.70 & 10 \\
\hline Model-fit statistics & Annual & Monthly & 7-day & Daily \\
\hline Number of years, months, days, or hours & 48 & 576 & 2,504 & 17,532 \\
\hline Root mean square error $\left(\mathrm{ft}^{3} / \mathrm{s}\right)$ & 54.0 & 220 & 488 & 751 \\
\hline RMSE as a percentage of the mean flow rate & -- & -- & 208 & 320 \\
\hline
\end{tabular}


Table 8. Streamflow calibration and testing results for the Hydrological Simulation Program—FORTRAN model of the middle Nueces River watershed, south Texas. - Continued

[acre-ft, acre-feet; $\mathrm{ft}^{3} / \mathrm{s}$, cubic feet per second; --, not applicable; RMSE, root mean squared error]

08194500 Nueces River near Tilden, Texas

Calibration period 2000-8

\begin{tabular}{|c|c|c|c|c|}
\hline $\begin{array}{c}\text { Comparison of } \\
\text { streamflow volumes }\end{array}$ & $\begin{array}{l}\text { Computed } \\
\text { streamflow }\end{array}$ & $\begin{array}{l}\text { Simulated } \\
\text { streamflow }\end{array}$ & $\begin{array}{c}\text { Error }^{1} \\
\text { (percent) }\end{array}$ & $\begin{array}{c}\text { Acceptance } \\
\text { criteria }^{2} \\
\text { (percent) }\end{array}$ \\
\hline Total flow volume, million acre-ft & 3.08 & 2.97 & -3.60 & 10 \\
\hline Mean flow rate $\left(\mathrm{ft}^{3} / \mathrm{s}\right)$ & 472 & 455 & -3.60 & 10 \\
\hline Total of highest 10 percent of daily flows, million acre- $\mathrm{ft}$ & 2.56 & 2.39 & -6.60 & 10 \\
\hline Model-fit statistics & Annual & Monthly & 7-day & Daily \\
\hline Number of years, months, days, or hours & 9 & 108 & 469 & 3,288 \\
\hline Root mean square error $\left(\mathrm{ft}^{3} / \mathrm{s}\right)$ & 87.0 & 468 & 1,736 & 2,380 \\
\hline RMSE as a percentage of the mean flow rate & -- & -- & 368 & 504 \\
\hline
\end{tabular}

Testing period 1990-99

\begin{tabular}{|c|c|c|c|c|}
\hline $\begin{array}{c}\text { Comparison of } \\
\text { streamflow volumes }\end{array}$ & $\begin{array}{l}\text { Computed } \\
\text { streamflow }\end{array}$ & $\begin{array}{c}\text { Simulated } \\
\text { streamflow }\end{array}$ & $\begin{array}{c}\text { Error }^{1} \\
\text { (percent) }\end{array}$ & $\begin{array}{c}\text { Acceptance } \\
\text { criteria }^{2} \\
\text { (percent) }\end{array}$ \\
\hline Mean flow rate $\left(\mathrm{ft}^{3} / \mathrm{s}\right)$ & 237 & 247 & 4.20 & 10 \\
\hline Total of highest 10 percent of daily flows, million acre- $\mathrm{ft}$ & 1.19 & 1.31 & 10.1 & 10 \\
\hline Model-fit statistics & Annual & Monthly & 7-day & Daily \\
\hline Number of years, months, days, or hours & 10 & 120 & 521 & 3,652 \\
\hline Root mean square error $\left(\mathrm{ft}^{3} / \mathrm{s}\right)$ & 51.0 & 207 & 488 & 772 \\
\hline RMSE as a percentage of the mean flow rate & -- & -- & 206 & 326 \\
\hline
\end{tabular}


Table 8. Streamflow calibration and testing results for the Hydrological Simulation Program—FORTRAN model of the middle Nueces River watershed, south Texas.-Continued

[acre-ft, acre-feet; $\mathrm{ft}^{3} / \mathrm{s}$, cubic feet per second; --, not applicable; RMSE, root mean squared error]

08194500 Nueces River near Tilden, Texas-Continued

Simulation period 1961-2008

\begin{tabular}{|c|c|c|c|c|}
\hline $\begin{array}{c}\text { Comparison of } \\
\text { streamflow volumes }\end{array}$ & $\begin{array}{l}\text { Computed } \\
\text { streamflow }\end{array}$ & $\begin{array}{c}\text { Simulated } \\
\text { streamflow }\end{array}$ & $\begin{array}{c}\text { Error }^{1} \\
\text { (percent) }\end{array}$ & $\begin{array}{c}\text { Acceptance } \\
\text { criteria }^{2} \\
\text { (percent) }\end{array}$ \\
\hline Total flow volume, million acre- $\mathrm{ft}$ & 13.4 & 11.8 & -11.7 & 10 \\
\hline Mean flow rate $\left(\mathrm{ft}^{3} / \mathrm{s}\right)$ & 385 & 340 & -11.7 & 10 \\
\hline Total of highest 10 percent of daily flows, million acre-ft & 11.1 & 9.62 & -13.3 & 10 \\
\hline Model-fit statistics & Annual & Monthly & 7-day & Daily \\
\hline Number of years, months, days, or hours & 48 & 576 & 2,504 & 17,532 \\
\hline Root mean square error $\left(\mathrm{ft}^{3} / \mathrm{s}\right)$ & 182 & 459 & 1,100 & 1,530 \\
\hline RMSE as a percentage of the mean flow rate & -- & -- & 286 & 397 \\
\hline
\end{tabular}

08210000 Nueces River near Three Rivers, Texas

Calibration period 2000-8

\begin{tabular}{|c|c|c|c|c|}
\hline Comparison of streamflow volumes & $\begin{array}{l}\text { Computed } \\
\text { streamflow }\end{array}$ & $\begin{array}{l}\text { Simulated } \\
\text { streamflow }\end{array}$ & $\begin{array}{c}\text { Error }^{1} \\
\text { (percent) }\end{array}$ & $\begin{array}{c}\text { Acceptance } \\
\text { criteria }^{2} \\
\text { (percent) }\end{array}$ \\
\hline Total flow volume, million acre-ft & 5.67 & 5.60 & -1.40 & 10 \\
\hline Mean flow rate $\left(\mathrm{ft}^{3} / \mathrm{s}\right)$ & 870 & 858 & -1.40 & 10 \\
\hline Total of highest 10 percent of daily flows, million acre-ft & 4.45 & 4.37 & -1.80 & 10 \\
\hline Model-fit statistics & Annual & Monthly & 7-day & Daily \\
\hline Number of years, months, days, or hours & 9 & 108 & 469 & 3,288 \\
\hline Root mean square error $\left(\mathrm{ft}^{3} / \mathrm{s}\right)$ & 101 & 475 & 823 & 1,390 \\
\hline RMSE as a percentage of the mean flow rate & -- & -- & 94.6 & 160 \\
\hline
\end{tabular}


Table 8. Streamflow calibration and testing results for the Hydrological Simulation Program—FORTRAN model of the middle Nueces River watershed, south Texas. - Continued

[acre-ft, acre-feet; $\mathrm{ft}^{3} / \mathrm{s}$, cubic feet per second; --, not applicable; RMSE, root mean squared error]

08210000 Nueces River near Three Rivers, Texas-Continued

Testing period 1990-99

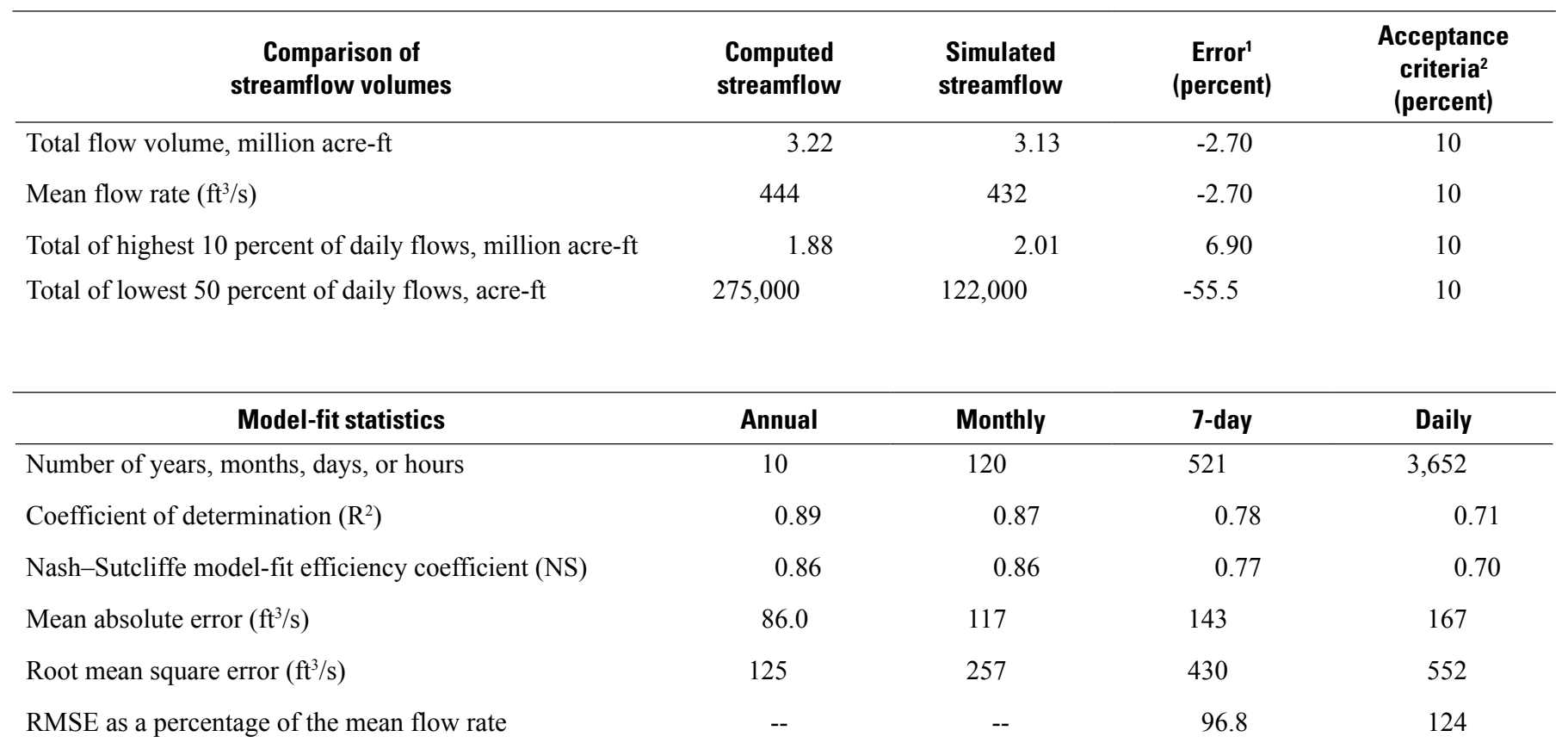

Simulation period 1961-2008

\section{Comparison of streamflow volumes}

Total flow volume, million acre- $\mathrm{ft}$

Mean flow rate $\left(\mathrm{ft}^{3} / \mathrm{s}\right)$

Total of highest 10 percent of daily flows, million acre- $\mathrm{ft}$

Total of lowest 50 percent of daily flows, acre-ft

\section{Computed streamflow}

24.6

708

18.6

694,000

Simulated
streamflow

16.0

460

13.1

52,800

Error $^{1}$
(percent)

$-35.0$

$-35.0$

$-29.8$

$-92.4$
Acceptance criteria $^{2}$ (percent)

10

10

10

10

\begin{tabular}{|c|c|c|c|c|}
\hline Model-fit statistics & Annual & Monthly & 7-day & Daily \\
\hline Coefficient of determination $\left(\mathrm{R}^{2}\right)$ & 0.80 & 0.81 & 0.76 & 0.67 \\
\hline Nash-Sutcliffe model-fit efficiency coefficient (NS) & 0.52 & 0.54 & 0.45 & 0.23 \\
\hline Mean absolute error $\left(\mathrm{ft}^{3} / \mathrm{s}\right)$ & 275 & 300 & 327 & 368 \\
\hline RMSE as a percentage of the mean flow rate & -- & -- & 184 & 247 \\
\hline
\end{tabular}

${ }^{1}$ Error $=[($ simulated-computed $) /$ computed $] \times 100$.

${ }^{2}$ Acceptance criteia from Bicknell and others (2001). 
Simulated streamflows and reservoir volumes also were evaluated graphically by comparing computed and simulated daily time-series and exceedance-probability (flow-duration) curves (Chow, 1964). Graphs of weekly time-series data, exceedance-probability curves, and scatterplots of computed weekly and simulated weekly streamflow are shown for the 2000-8 calibration period at the following USGS streamflowgaging stations:

- Site Q2 - 08193000 Nueces River near Asherton, Tex. (fig. 9),

- Site Q3 - 08194000 Nueces River at Cotulla, Tex. (fig. 10),

- Site Q5 - 08194500 Nueces River near Tilden, Tex. (fig. 11), and

- Site Q6 - 08210000 Nueces River near Three Rivers, Tex. (fig. 12).

Donigian and others (1984) provided general guidelines for characterizing HSPF calibrations. Model calibration is considered "very good" when the error is less than 10 percent, "good" when the error is within 10-15 percent, "fair" when the error is within 15-25 percent, and "poor" when the error is greater than 25 percent. According to these guidelines, 2000-8 calibration results for total flow volume at the four long-term calibration stations are considered good to very good for total flow volume and for the volume of the highest 10 percent of daily flows (table 8). Calibration results for streamflow volumes of the lowest 50 percent of daily flows are considered poor (table 8). For the calibration period, the NS for daily streamflows ranged from 0.15 to 0.80 (table 8). Smaller NS values (compared to the optimal value of 1.0) were caused by the difficulty in matching simulated to computed flows during periods of sudden, intense runoff as well as in correctly simulating the timing of the flows routed from upstream from the study area. Seven-day averaging improved the model statistics such that the NS ranged from 0.25 to 0.91 (table 8). The RMSE ranged from 160 to 504 percent of the mean flow rate. The daily streamflow calibration at USGS streamflowgaging station 08021000 Nueces River near Three Rivers, Tex., had the lowest (best) RMSE, and USGS streamflowgaging station 08194500 Nueces River near Tilden, Tex., had the highest RMSE expressed as a percentage of the mean flow rate.

A time series of mean daily Lake Corpus Christi reservoir volume during 1961-2008 was output from the Mathis subwatershed model by using the volume of RCHRES 132 (fig. 13). This volume was compared with reservoir volume computed at USGS streamflow-gaging station 08210500 during this same period (fig. 3, table 3, site Q8) (U.S. Geological Survey, 2011). Computed and simulated mean weekly reservoir volumes were graphically compared for 1992-2008, which includes reservoir volume calibration and testing periods. The reservoir volume testing period was slightly different than the streamflow testing period in order to start the testing period with a full reservoir (fig. 13). The mean daily reservoir volume during 1961-2008 was 182,000 acre-ft. Simulated mean daily reservoir volume was within 9 percent of this computed volume. The daily $\mathrm{R}^{2}$ and NS coefficients for the daily comparison of 1961-2008 simulated and computed reservoir volume were 0.91 and 0.63 , respectively, with a RMSE of 19 percent.

\section{Evapotranspiration}

In addition to accurate simulation of streamflow, another goal of the middle Nueces River watershed model calibration was to accurately simulate the overall water budget in the watershed, including evapotranspiration. The USGS 290810099212100 southwest Medina County meteorological station near D'Hanis, Tex. (hereinafter the Medina County meteorological station) (fig. 3, table 3, site ET1), was installed in September 2006 on land with primarily shrub vegetation on the Carrizo-Wilcox aquifer outcrop area (Slattery and others, 2011). The daily evapotranspiration at this meteorological station was computed by using the eddy covariance method (Slattery and others, 2011). The eddy covariance method is a statistical method that calculates vertical turbulent fluxes within atmospheric boundary layers on the basis of measured micrometeorological data, including wind and scalar atmospheric data series, and produces values of fluxes for properties that are used to estimate evapotranspiration (Bidlake, 2002).

The Sycamore and Asherton subwatershed model calibrations included comparing simulated evapotranspiration from the Carrizo-Wilcox aquifer outcrop area of the Sycamore and Asherton subwatersheds to evapotranspiration estimates from data collected at the Medina County meteorological station during August 2006-December 2008 (fig. 14). Missing data at the Medina County meteorological station were interpolated between the values computed during the nearest days. The total amount of evapotranspiration computed at the station was 54.7 in for this time period (August 2006December 2008), and the total simulated evapotranspiration from the Carrizo-Wilcox aquifer outcrop area in the Sycamore and Asherton subwatersheds was 47.8 in. The simulated evapotranspiration was 13 percent less than was the computed evapotranspiration. The total rainfall measured by a tipping bucket rain gage at the Medina County meteorological station from October 2006-December 2008 was 57.0 in with 10 days of missing record (Richard Slattery, U.S. Geological Survey, written commun., 2010), whereas the rainfall used in the model simulation derived from rainfall recorded at the NWS meteorological station 414920 at La Pryor, Tex. (table 1, fig. 3, site P2), and NWS meteorological station 411486 at Carrizo Springs 3W, Carrizo Springs, Tex. (table 1, fig. 3, site P3), was 49.9 in. A comparison of computed evapotranspiration to measured rainfall at the Medina County meteorological station (table 3, fig. 3, site ET1) shows that approximately 96 percent of the rainfall during October 2006-December 2008 evapotranspired. 

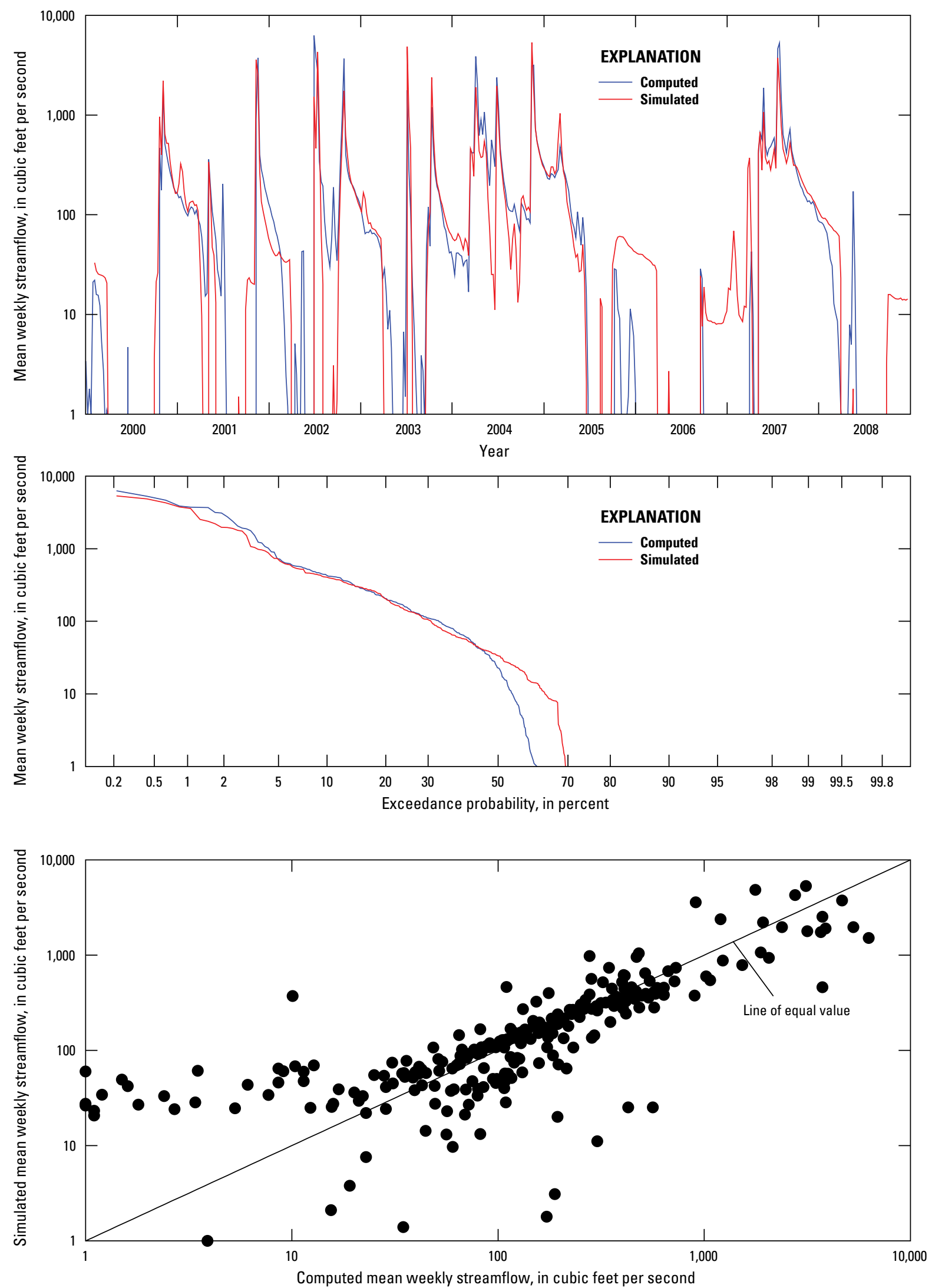

Figure 9. Computed and simulated mean weekly streamflow at streamflow-gaging station 08193000 Nueces River near Asherton, Texas, 2000-8. 

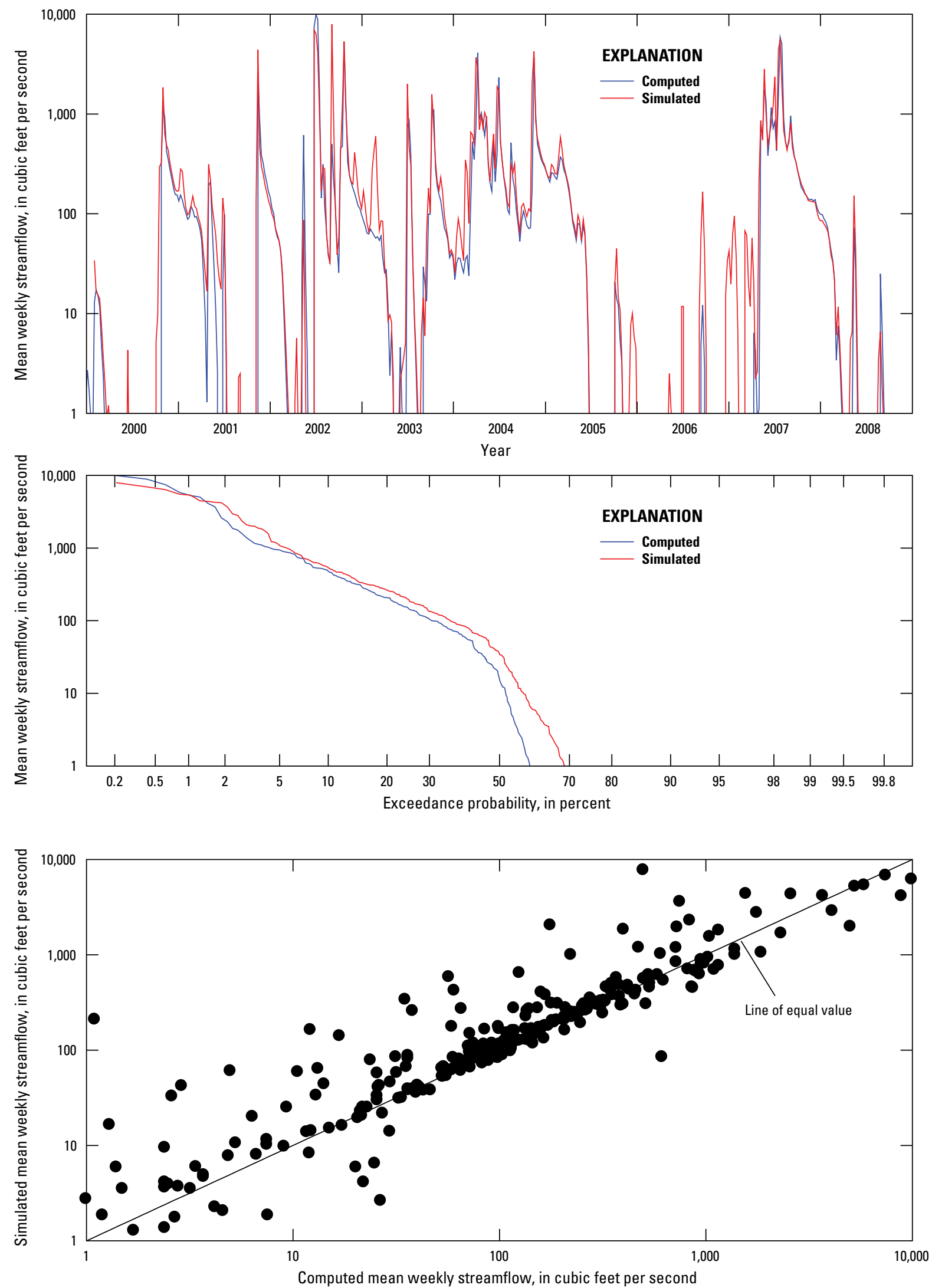

Figure 10. Computed and simulated mean weekly streamflow at streamflow-gaging station 08194000 Nueces River at Cotulla, Texas, 2000-8. 

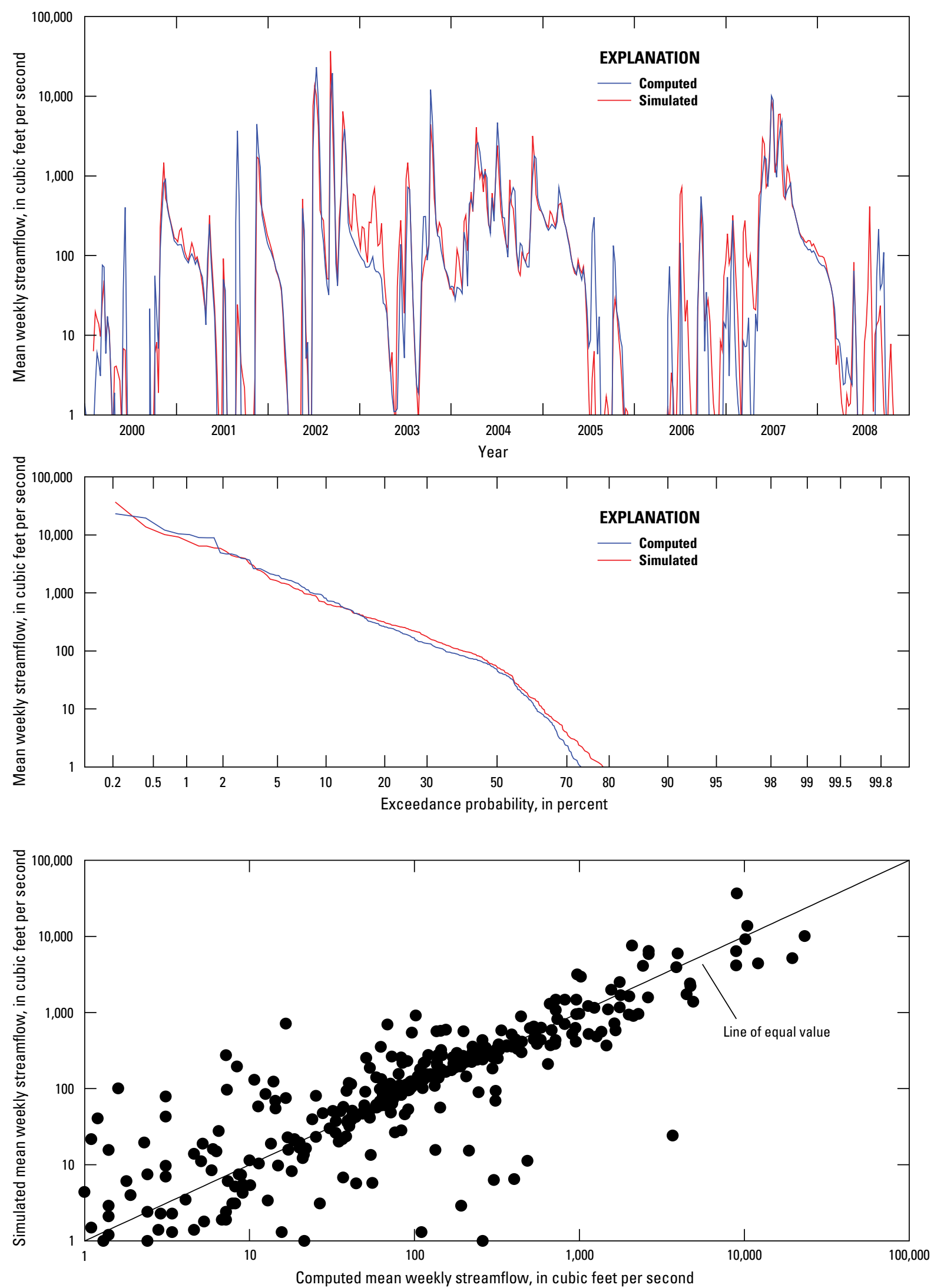

Figure 11. Computed and simulated mean weekly streamflow at streamflow-gaging station 08194500 Nueces River near Tilden, Texas, $2000-8$. 

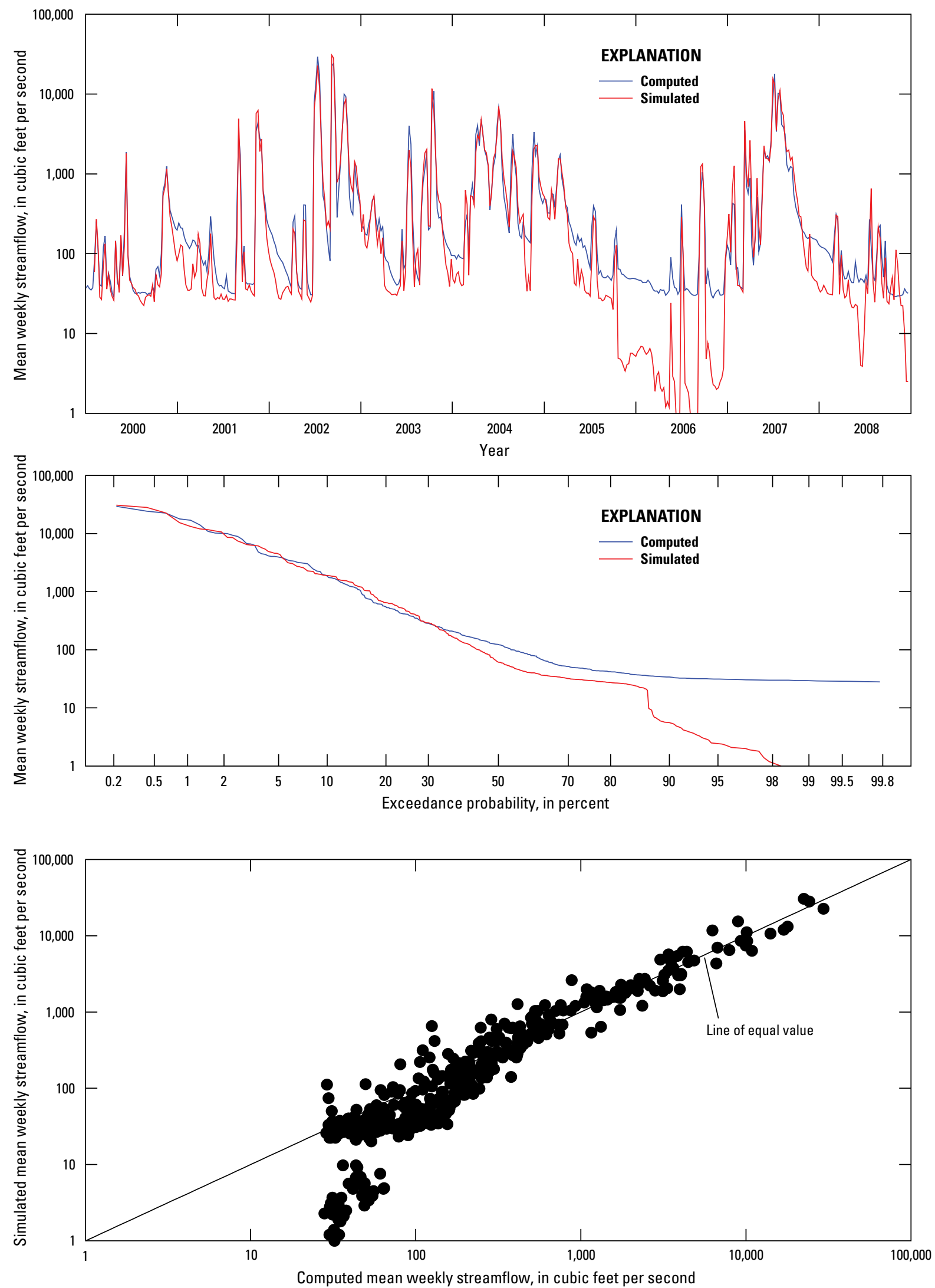

Figure 12. Computed and simulated mean weekly streamflow at streamflow-gaging station 08210000 Nueces River near Three Rivers, Texas, 2000-8. 

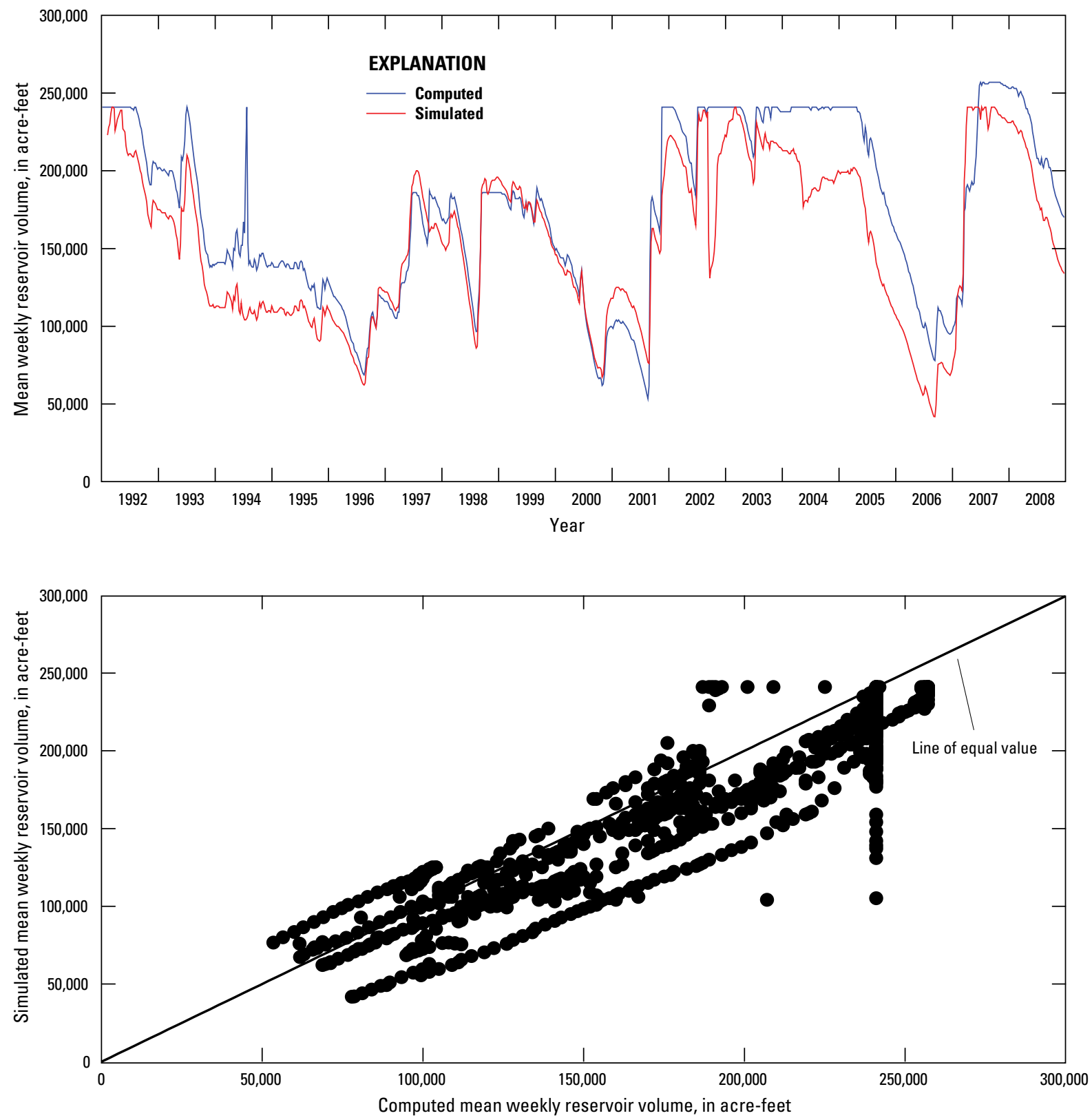

Figure 13. Computed and simulated mean weekly reservoir volume of Lake Corpus Christi, south Texas, 1992-2008.

\section{Sensitivity Analysis}

Calibrated values of selected HSPF-process-related parameters in the Sycamore subwatershed were further evaluated by doing a sensitivity analysis. The Sycamore subwatershed was used for sensitivity analysis because it contains a larger part of the Carrizo-Wilcox aquifer outcrop compared to any other subwatershed in the study. The analysis used the calibrated model parameters in the Sycamore subwatershed (table 7) to determine the effects of systematic changes to the values of eight selected model parameters on simulated evapotranspiration, groundwater recharge (from rainfall), and surface runoff from the PERLND areas in the outcrop area of the Carrizo-Wilcox aquifer where it crosses the Sycamore subwatershed (fig. 5). The calibrated model parameter set produced mean annual evapotranspiration, groundwater recharge, and surface runoff estimates for 2000-8 of 20.2, 1.2, and 0.5 in, respectively, for the Carizzo-Wilcox 

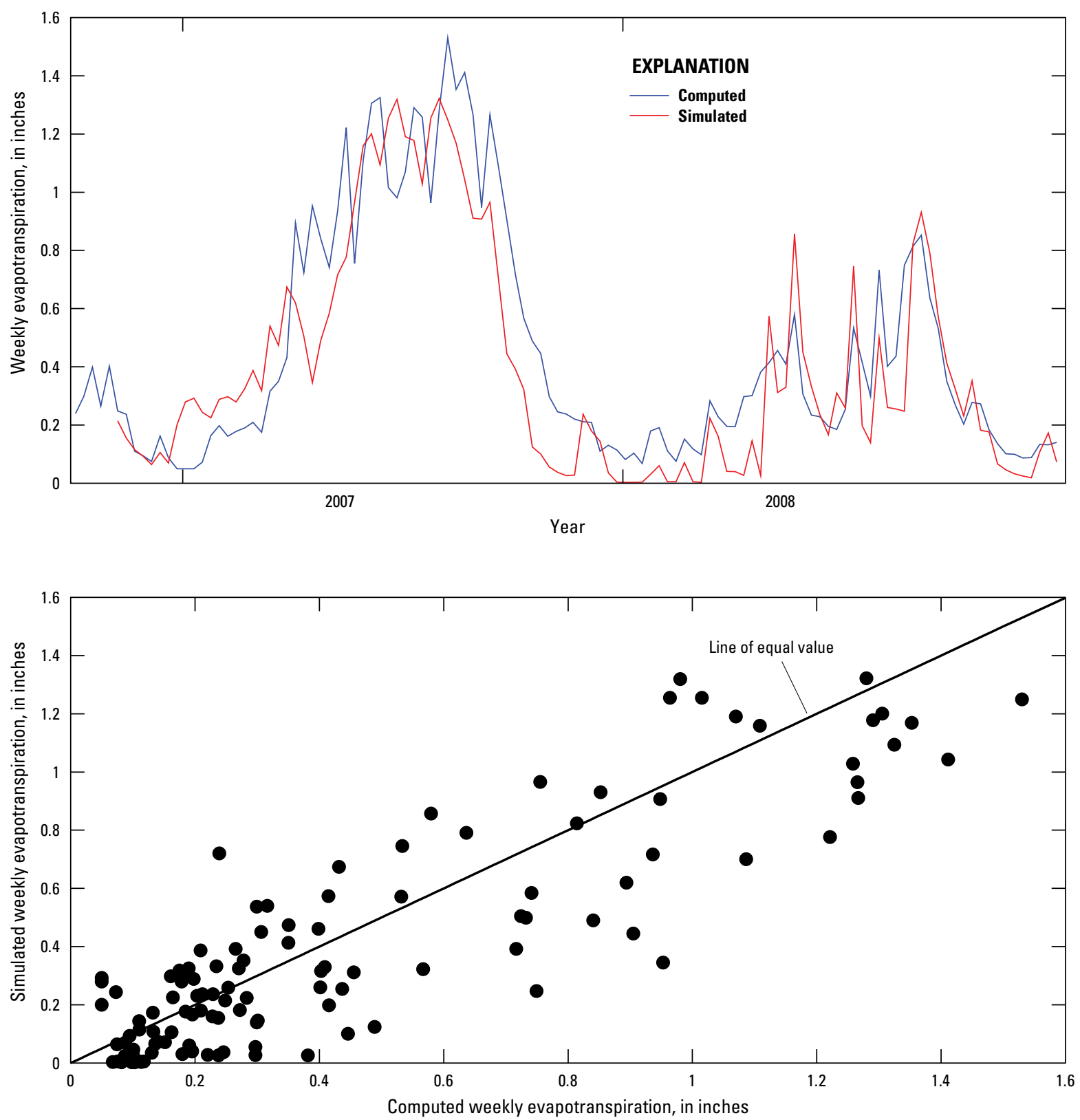

Figure 14. Computed weekly evapotranspiration at U.S. Geological Survey 290810099212100 southwest Medina County meteorological station near D'Hanis, Texas, and weekly evapotranspiration simulated by using the Hydrological Simulation Program—FORTRAN model for the Carrizo-Wilcox aquifer outcrop area in the Sycamore and Asherton subwatersheds of the middle Nueces River watershed, south Texas, October 2006-December 2008.

aquifer outcrop (table 9). For each simulation, a selected model parameter of the Sycamore subwatershed was changed by a hydrologically reasonable amount (table 9) while keeping all other model parameters unchanged. The resulting changes in mean annual evapotranspiration, groundwater recharge, and surface runoff for the Carrizo-Wilcox aquifer outcrop area in the Sycamore subwatershed are listed in table 9. The model parameters to which estimated recharge was most sensitive for the given model parameter changes were lower zone nominal storage (LZNS), lower zone evapotranspiration (LZETP), and the fraction of groundwater inflow to deep recharge (DEEPFR). 


\section{Model Limitations}

Model limitations include errors related to model conceptualization and parameter variability, lack of data to better quantify certain model inputs such as rainfall and irrigation, and measurement errors. HSPF is a complex watershed model that can handle multiple hydrologic scenarios; however, the models that were developed for these relatively large subwatersheds represent a simplified understanding of the hydrologic processes of the middle Nueces River watershed. Not only are the natural hydrologic processes more complex than the theoretical and empirical equations embedded in modeling software such as HSPF, but the spatial scales of variation in those processes also are not realistically represented by the nearly uniform parameter values applied to all PERLNDs throughout a subwatershed model. The conceptualization of the watershed-FTABLES, stream dimensions, surface withdrawals, and the imposed variation in model parameters - based on decisions as to which watershed factors drive the hydrologic responses of the watershed represents a simplification of the complex nature of the study watershed. In general, HSPF distributes inflows and outflows to maintain a balanced water budget as process parameters are changed, but it is dependent on the model developers to maintain a realistic water budget when processes such as surface withdrawals and return flows are incorporated into the models. The accuracy of the modeled distribution of water within the entire middle Nueces River watershed depends on the adequacy of the measured data used in computations to calibrate the model, and the accuracy of the modeled distribution of water within a given subwatershed model is essentially unknown because no measured data were available at those smaller scales.

Most of the rainfall in the study area evapotranspires, yet few computed evapotranspiration data are available. The lack of measurements for computation of evapotranspiration data for different surficial geologic units, land covers, vegetative types, and seasons could cause systematic errors in representing the hydrologic processes of the watershed.

Because intense, isolated storms are common in south Texas, rainfall can vary greatly over a short distance. Uncertainty regarding the degree to which available rainfall data represent actual rainfall is potentially the most serious source of error for the middle Nueces River watershed model. Hourly rainfall input to the model was disaggregated from measured daily rainfall at 11 NWS meteorological stations by using theoretical temporal distributions. Thiessen areas surrounding the 11 NWS meteorological stations were determined, and the disaggregated rainfall amounts were applied evenly to these areas. Because of the highly localized

Table 9. Sensitivity of the estimated mean annual evapotranspiration, groundwater recharge, and surface runoff for the CarrizoWilcox aquifer outcrop to changes in selected model parameters of the Hydrological Simulation Program—FORTRAN model of the Sycamore subwatershed, south Texas, 2000-8.

[LZSN, lower zone nominal storage; UZSN, upper zone nominal storage; LZETP, lower zone evapotranspiration; INFILT, index to infiltration capacity of soil; DEEPFR, fraction of groundwater inflow to deep recharge; AGWRC, groundwater recession indexed to rate of drainage; AGWETP, fraction of remaining evapotranspiration from groundwater; CEPSC, interception storage capacity]

\begin{tabular}{|c|c|c|c|c|c|c|c|c|c|}
\hline \multirow[b]{2}{*}{$\begin{array}{c}\text { Model } \\
\text { parameter }\end{array}$} & \multirow[b]{2}{*}{$\begin{array}{l}\text { Initial } \\
\text { value }\end{array}$} & \multirow[b]{2}{*}{ Unit } & \multirow[b]{2}{*}{$\begin{array}{l}\text { Adjusted } \\
\text { value }\end{array}$} & \multicolumn{6}{|c|}{ Carrizo-Wilcox aquifer outcrop area in the Sycamore subwatershed } \\
\hline & & & & $\begin{array}{l}\text { Evapotrans- } \\
\text { piration } \\
\text { (inches) }\end{array}$ & $\begin{array}{c}\text { Change in } \\
\text { evapotrans- } \\
\text { piration } \\
\text { (percent) }\end{array}$ & $\begin{array}{l}\text { Ground- } \\
\text { water } \\
\text { recharge } \\
\text { (inches) }\end{array}$ & $\begin{array}{l}\text { Change in } \\
\text { groundwater } \\
\text { recharge } \\
\text { (percent) }\end{array}$ & $\begin{array}{c}\text { Surface } \\
\text { runoff } \\
\text { (inches) }\end{array}$ & $\begin{array}{c}\text { Change } \\
\text { in surface } \\
\text { runoff } \\
\text { (percent) }\end{array}$ \\
\hline LZSN & 4.5 & Inches & Increase by 1.0 & 20.1 & -0.5 & 0.96 & -20 & 0.4 & -27 \\
\hline UZSN & 1.0 & Inches & Increase by 0.5 & 19.9 & -1.5 & 1.1 & -7 & 0.4 & -20 \\
\hline LZETP & $0.2-0.9$ & None & Increase by 0.10 & 20.0 & -1.0 & 1.0 & -15 & 0.4 & -21 \\
\hline INFILT & 0.8 & Inches/hour & Increase by 0.05 & 19.8 & -2.0 & 1.1 & -5 & 0.5 & -11 \\
\hline DEEPFR & 0.7 & None & Decrease by 0.10 & 19.8 & -2.0 & 0.97 & -19 & 0.6 & 19 \\
\hline AGWRC & 0.9 & $1 /$ day & Increase by 0.05 & 19.9 & -1.5 & 1.1 & -6 & 0.4 & -21 \\
\hline AGWETP & 0.0 & None & Increase by 0.03 & 19.8 & -2.0 & 1.1 & -5 & 0.4 & -18 \\
\hline CEPSC & 0.4 & Inches & Increase by 0.05 & 19.9 & -1.5 & 1.1 & -9 & 0.4 & -14 \\
\hline
\end{tabular}

${ }^{1}$ Compared to the calibrated model, estimated amounts of mean annual evapotranspiration, groundwater recharge, and surface runoff of 20.2, 1.2 , and 0.5 inches, respectively. 
nature of rainfall in south Texas, the disaggregated rainfall time-series data applied by using Thiessen areas do not always accurately represent the rainfall duration or intensity in the study area. Simulation results were improved by using the inverse distance method for converting measured point rainfall into a spatial distribution of rainfall for the Mathis subwatershed model. The lack of main-stem reservoirs to compare simulated and observed reservoir storage did not allow similar testing of alternative distribution methods in other subwatersheds. In addition, missing daily rainfall records at the 11 NWS meteorological stations were estimated with nearby station data, which make the applied rainfall data less accurate (tables 1 and 2). Channel losses (seepage of streamflow into the channel bed and banks, or infiltration where the stream crosses aquifer outcrops) are accounted for indirectly during the calibration of the model. During periods of runoff from large storms, channel losses might be appreciable, but because channel losses are not measured directly, the amount of channel losses is unknown.

The emphasis during calibration of most HSPF models is limited to the accurate simulation of streamflow. Streamflow accounts for a relatively small percentage of the water budget in the study area. Although an accurate calibration of streamflow relates to the accurate simulation of all of the components of the water cycle, the accuracy of groundwaterrecharge estimation also depends on accurate calibration of other water-budget components, especially evapotranspiration. The dependence is evidenced by the results of the sensitivity analysis; changes in some of the modeled parameters had an effect on the distribution of water between groundwater recharge and evapotranspiration and a limited effect on the amount of surface runoff. Data for evapotranspiration on the outcrop area of the Carrizo-Wilcox aquifer in Medina County during October 2006-December 2008 were available and used in model calibration, but these data were from outside the model area. Differences between the computed and simulated weekly evapotranspiration data were not large, and the simulated evapotranspiration data appear reasonable; however, there is uncertainty in the modeled values of evapotranspiration because the Medina station is outside the modeled area.

Irrigation represents the largest use of water in the study area, and groundwater has historically been the source of water for irrigation as well as other uses; surface-water withdrawals make up a small percentage of the water needed for irrigation and other uses in the study area (Texas Water Development Board, 2007). With the exception of modeling surface-water irrigation diversion amounts (table 6) as a disaggregated time series of equal daily amounts during April through September of each year, however, other components of irrigation (including the application and distribution of water from groundwater sources) were not modeled in the study area, nor were withdrawals less than 724 acre-ft/yr $\left(1.0 \mathrm{ft}^{3} / \mathrm{s}\right)$. This greatly simplified the model development and data needs, but the exact timing and efficiency of irrigation processes could affect the modeling of recharge rates and surface runoff.

\section{Streamflow Yields, 1961-2008}

The input and simulated output of the calibrated 2000-8 middle Nueces River watershed model and the principles of the RCHRES water balance were utilized to quantify and compare the estimated streamflow yield from each subwatershed. Watershed streamflow yields are often calculated to assess the production of surficial streamflow while normalizing for drainage area. Streamflow yield can vary substantially on an annual basis because of fluctuations in annual rainfall, but mean annual streamflow yield can be a useful measure for evaluating streamflow production and hydrologic differences between watersheds. In addition, this quantification and comparison serves to help document the model calibration and also demonstrates another useful output from the model. For each subwatershed, the mean annual yield was calculated as the difference between the simulated mean annual streamflow volumes exiting and entering each subwatershed divided by the subwatershed drainage area, as illustrated in the following equation:

$$
\mathrm{Y}=\left(\mathrm{Q}_{\text {out }}-\mathrm{Q}_{\text {in }}\right) \mathrm{F} / \mathrm{DA},
$$

where

$$
\begin{aligned}
& \mathrm{Y} \begin{array}{c}
\text { is mean annual streamflow yield, in inches } \\
\text { per year; } \\
\mathrm{Q}_{\text {out }} \text { and } \mathrm{Q}_{\mathrm{in}}
\end{array} \\
& \begin{array}{c}
\text { are mean annual streamflow volumes } \\
\text { exiting and entering the drainage area, } \\
\text { respectively, in acre-feet; }
\end{array} \\
& \mathrm{F} \quad \begin{array}{l}
\text { is a unit conversion factor (0.0187); and } \\
\text { is the drainage area within the study area, in } \\
\text { square miles. }
\end{array}
\end{aligned}
$$

The difference between $\mathrm{Q}_{\text {out }}$ and $\mathrm{Q}_{\text {in }}$ equals the estimated overall gain (positive value) or loss (negative value) in streamflow volume, in acre-ft, excluding gains from springflow and wastewater-treatment plants but including losses from surface-water withdrawals (from water rights permits) and channel infiltration and overbank (flood) losses (accounted for indirectly during the calibration of the model). During periods of runoff from large storms, channel infiltration and overbank (flood) losses might be appreciable, but because channel infiltration and overbank (flood) losses are not measured directly, the amount of channel losses is unknown (Lizárraga and Ockerman, 2011).

Model-estimated mean annual streamflow yields from the eight subwatersheds ranged from -2.4 to 6.5 inches per year (in/yr), with yields greatest in the Mathis subwatershed and lowest in the Three Rivers subwatershed (table 10). The areaweighted mean yield of the eight subwatersheds was $1.12 \mathrm{in} / \mathrm{yr}$ for 1961-2008. 


\section{Groundwater Recharge in the Carrizo-Wilcox Aquifer Outcrop Area, 1961-2008}

Quantifying groundwater recharge in Texas is an important component of statewide water-resource planning (Scanlon and others, 2003). The middle Nueces River watershed model was configured to output annual estimates of the groundwater recharge and other major water-budget components - rainfall, evapotranspiration, and surface runoff- for the part of the Carrizo-Wilcox aquifer outcrop area in the study area. Selectively summarizing the model results in this manner demonstrates one use of the calibrated model for water-resource planning. Future scenarios, such as increased impervious land cover in the watershed or decreased rainfall, could be simulated to project changes to the groundwater recharge rates to this part of the Carrizo-Wilcox aquifer outcrop area.
The annual estimates of the water-budget components from two subwatersheds with streams flowing across part of the Carrizo-Wilcox aquifer outcrop area (fig. 1) were spatially weighted to determine the estimated amounts of annual rainfall, evapotranspiration, groundwater recharge, and surface runoff for the Carrizo-Wilcox aquifer outcrop area during 1961-2008 (table 11). The mean annual rainfall on the Carrizo-Wilcox aquifer outcrop area during the 1961-2008 simulation period was approximately $21.7 \mathrm{in}$. Of this rainfall, an annual mean of approximately 20.1 in (about 93 percent) was simulated as evapotranspiration; 1.2 in (about 6 percent) was simulated as groundwater recharge; and 0.5 in (about 2 percent) was simulated as surface runoff. Estimated annual groundwater recharge in the Carrizo-Wilcox aquifer outcrop area varied from 0.0 to 5.5 in depending on the amount of rainfall. These recharge estimates are consistent with recharge values compiled from the literature (Scanlon and others, 2003; Kelley and others, 2004).

Table 10. Simulated mean annual streamflow volumes and yields generated from subwatersheds in the Hydrological Simulation Program—FORTRAN model of the middle Nueces River watershed, south Texas, 1961-2008.

$\left[\mathrm{mi}^{2}\right.$, square miles; $\mathrm{Q}_{\text {out }}$, mean annual streamflow volume exiting the drainage area; acre-ft/yr, acre-feet per year; $\mathrm{Q}_{\text {in }}$, mean annual streamflow volumes entering the drainage area; in, inches]

\begin{tabular}{lccccc}
\hline $\begin{array}{c}\text { Subwatershed } \\
\text { name }\end{array}$ & $\begin{array}{c}\text { Drainage area within } \\
\text { the study area } \\
\left(\mathbf{m i}^{2}\right)\end{array}$ & $\begin{array}{c}\mathbf{0}_{\text {out }} \\
\text { (acre-ft) }\end{array}$ & $\begin{array}{c}\mathbf{0}_{\text {in }} \\
\text { (acre-ft) }\end{array}$ & $\begin{array}{c}\mathbf{0}_{\text {out }} \mathbf{0}_{\text {in }} \\
\text { (acre-ft) }\end{array}$ & $\begin{array}{c}\text { Mean annual } \\
\text { streamflow yield } \\
\text { (in) }\end{array}$ \\
\hline Sycamore & 1,670 & 40,600 & 0 & 40,600 & 0.5 \\
Asherton & 503.0 & 158,000 & 164,500 & $-6,500$ & -0.2 \\
Cotulla & 1,143 & 178,000 & 141,300 & 36,700 & 0.6 \\
Artesia Wells & 1,265 & 196,000 & 170,200 & 25,800 & 0.4 \\
San Casimiro & 546.0 & 27,400 & 0.4 & 0.9 \\
Tilden & 1,118 & 246,000 & 223,400 & 27,400 & 0.4 \\
Three Rivers & 417.0 & 333,000 & 385,900 & $-52,900$ & -2.4 \\
Mathis & 1,064 & 881,000 & 512,900 & 368,100 & 6.5 \\
\hline
\end{tabular}

${ }^{1}$ Mean annual streamflow yield $=\left(\mathrm{Q}_{\text {out }}-\mathrm{Q}_{\text {in }}\right)(0.0187) /$ drainage area within the study area 
Table 11. Estimated annual rainfall, evapotranspiration, groundwater recharge, and surface runoff for the Carrizo-Wilcox aquifer outcrop area in the middle Nueces River watershed, south Texas, 1961-2008.

[in, inches]

\begin{tabular}{|c|c|c|c|c|}
\hline $\begin{array}{l}\text { Year or } \\
\text { period }\end{array}$ & $\begin{array}{l}\text { Rainfall' } \\
\text { (in) }\end{array}$ & $\begin{array}{c}\text { Evapotrans- } \\
\text { piration } \\
\text { (in) }\end{array}$ & $\begin{array}{l}\text { Groundwater } \\
\text { recharge } \\
\text { (in) }\end{array}$ & $\begin{array}{c}\text { Surface } \\
\text { runoff } \\
\text { (in) }\end{array}$ \\
\hline 1961 & 15.6 & 19.1 & 0.5 & 0.1 \\
\hline 1962 & 12.5 & 12.3 & 0.0 & 0.0 \\
\hline 1963 & 16.8 & 15.5 & 0.1 & 0.0 \\
\hline 1964 & 23.1 & 19.1 & 1.8 & 0.7 \\
\hline 1965 & 21.7 & 21.4 & 1.3 & 0.4 \\
\hline 1966 & 19.8 & 20.5 & 0.8 & 0.3 \\
\hline 1967 & 21.3 & 15.8 & 1.5 & 0.5 \\
\hline 1968 & 25.4 & 24.2 & 2.2 & 0.8 \\
\hline 1969 & 24.5 & 18.9 & 1.7 & 0.6 \\
\hline 1970 & 21.4 & 24.3 & 1.1 & 0.3 \\
\hline 1971 & 34.2 & 23.1 & 5.5 & 2.4 \\
\hline 1972 & 17.9 & 20.9 & 0.2 & 0.0 \\
\hline 1973 & 31.8 & 25.7 & 2.5 & 0.9 \\
\hline 1974 & 19.5 & 20.1 & 0.4 & 0.1 \\
\hline 1975 & 22.3 & 22.9 & 0.4 & 0.1 \\
\hline 1976 & 34.0 & 25.7 & 2.8 & 1.0 \\
\hline 1977 & 14.3 & 18.5 & 0.4 & 0.1 \\
\hline 1978 & 21.1 & 19.5 & 0.7 & 0.2 \\
\hline 1979 & 18.5 & 18.8 & 1.2 & 0.4 \\
\hline 1980 & 19.8 & 16.3 & 0.8 & 0.2 \\
\hline 1981 & 26.7 & 25.0 & 2.7 & 1.0 \\
\hline 1982 & 17.8 & 15.8 & 0.1 & 0.0 \\
\hline 1983 & 12.3 & 13.8 & 0.1 & 0.0 \\
\hline 1984 & 16.4 & 12.1 & 0.8 & 0.3 \\
\hline 1985 & 23.7 & 22.9 & 1.5 & 0.5 \\
\hline
\end{tabular}

\begin{tabular}{lcccc}
\hline $\begin{array}{c}\text { Year or } \\
\text { period }\end{array}$ & $\begin{array}{c}\text { Rainfall }{ }^{1} \\
\text { (in) }\end{array}$ & $\begin{array}{c}\text { Evapotrans- } \\
\text { piration } \\
\text { (in) }\end{array}$ & $\begin{array}{c}\text { Groundwater } \\
\text { recharge } \\
\text { (in) }\end{array}$ & $\begin{array}{c}\text { Surface } \\
\text { runoff } \\
\text { (in) }\end{array}$ \\
\hline 1986 & 29.3 & 22.1 & 2.7 & 1.0 \\
1987 & 28.6 & 28.5 & 4.2 & 1.7 \\
1988 & 12.5 & 12.5 & 0.0 & 0.0 \\
1989 & 17.9 & 16.7 & 0.3 & 0.1 \\
1990 & 33.6 & 29.1 & 3.4 & 1.4 \\
1991 & 22.4 & 20.3 & 0.2 & 0.0 \\
1992 & 28.6 & 26.9 & 2.9 & 1.1 \\
1993 & 15.2 & 15.7 & 0.2 & 0.0 \\
1994 & 26.7 & 23.0 & 0.8 & 0.2 \\
1995 & 19.8 & 20.6 & 0.3 & 0.1 \\
1996 & 11.9 & 12.5 & 0.0 & 0.0 \\
1997 & 24.5 & 23.5 & 0.6 & 0.2 \\
1998 & 21.8 & 19.3 & 0.6 & 0.1 \\
1999 & 21.1 & 22.1 & 0.8 & 0.2 \\
2000 & 17.0 & 12.9 & 0.5 & 0.2 \\
2001 & 17.0 & 19.6 & 0.5 & 0.1 \\
2002 & 29.7 & 22.5 & 2.9 & 1.3 \\
2003 & 30.8 & 28.2 & 2.6 & 1.6 \\
2004 & 31.9 & 27.4 & 2.2 & 0.7 \\
2005 & 13.3 & 15.5 & 0.8 & 0.3 \\
2006 & 14.3 & 13.4 & 0.2 & 0.1 \\
2007 & 30.5 & 29.9 & 1.3 & 0.3 \\
2008 & 12.5 & 12.2 & 0.1 & 0.0 \\
$1961-2008$ & 21.7 & 20.1 & 1.2 & 0.5 \\
\hline & & & & \\
\hline
\end{tabular}

${ }^{1}$ Water is stored in various unsaturated zones of the model on an annual basis, so the annual precipitation does not necessarily equal the annual evapotranspiration, groundwater recharge, and surface runoff amounts.

\section{Summary}

The U.S. Geological Survey (USGS) - in cooperation with the U.S. Army Corps of Engineers, Fort Worth District; City of Corpus Christi; Guadalupe-Blanco River Authority; San Antonio River Authority; and San Antonio Water System - configured, calibrated, and tested a watershed model for a study area consisting of about 7,726 square miles of the middle Nueces River watershed in south Texas. The middle Nueces River watershed begins north of the Carrizo-Wilcox aquifer outcrop area and extends to the outflow of Lake Corpus Christi, excluding Choke Canyon Reservoir tributary watersheds and the Atascosa River watershed.

Because of the large size of the study area, the middle Nueces River watershed was divided into eight subwatershed models; separate Hydrological Simulation ProgramFORTRAN models were developed for each subwatershed.
The subwatershed models were configured to generate output at streamflow locations where there is existing gage information, for the reservoir volume at Lake Corpus Christi, and for the Carrizo-Wilcox aquifer outcrop area. The model was used to simulate streamflow at gages and subwatershed outlets, reservoir volume, evapotranspiration, and groundwater recharge for the Carrizo-Wilcox aquifer outcrop area.

Rainfall data used as input for the model were obtained from 11 National Weather Service meteorological stations in or near the study area. Air temperature data from five of the National Weather Service meteorological stations were used to estimate potential evapotranspiration in the model. Outputs from an existing Hydrological Simulation ProgramFORTRAN model for the lower Frio River watershed were used as additional inputs to the Three Rivers subwatershed model where the Frio River enters the Nueces River.

Although all nine USGS streamflow-gaging stations were used for model configuration, only four could be used 
in both model calibration and testing because they were not used to define the flow entering or leaving the subwatershed (subwatershed boundary conditions). Using various graphical and statistical methods, the $2000-8$ calibration results were characterized as good to very good for total flow volumes and for the volume of the highest 10 percent of daily flows. Calibration results for streamflow volumes of the lowest 50 percent of daily flows were considered poor. For the calibration period, the Nash-Sutcliffe model-fit efficiency coefficient (NS) for daily streamflows ranged from 0.15 to 0.80 . Smaller NS values (compared to the optimal value of 1.0) were caused by the difficulty in matching simulated to computed flows during periods of sudden, intense surface runoff as well as correctly simulating the timing of the flows routed from upstream from the study area. Seven-day averaging improved the model statistics such that the NS ranged from 0.25 to 0.91 and the root mean square error (RMSE) ranged from 160 to 504 percent of the mean flow rate. The streamflow calibration at USGS streamflow-gaging station 08210000 Nueces River near Three Rivers, Tex., had the lowest (best) RMSE, and USGS streamflow-gaging station 08194500 Nueces River near Tilden, Tex., had the highest RMSE as a percent of the mean flow rate. Simulated 19612008 mean daily reservoir volume was within 9 percent of the computed volume.

The Sycamore and Asherton subwatershed model calibrations included comparing simulated evapotranspiration from the Carrizo-Wilcox aquifer outcrop area of the Sycamore and Asherton subwatersheds to evapotranspiration estimates from data collected at the USGS 290810099212100 southwest Medina County meteorological station during August 2006December 2008. The total amount of evapotranspiration computed at the station was 54.7 inches (in) for this time period, and the total simulated evapotranspiration from the Carrizo-Wilcox aquifer outcrop area in the Sycamore and Asherton subwatersheds was 47.8 in. The simulated evapotranspiration was 13 percent less than the computed evapotranspiration. Approximately 96 percent of the rainfall during October 2006-December 2008 evapotranspired.

Calibrated values of selected HSPF-process-related parameters in the Sycamore subwatershed were further evaluated by doing a sensitivity analysis. The Sycamore subwatershed was used for sensitivity analysis because it contains more area of the Carrizo-Wilcox aquifer outcrop area than does any other subwatershed in the study. The model parameters to which estimated recharge was most sensitive for the given model parameter changes were lower zone nominal storage (LZNS), lower zone evapotranspiration (LZETP), and the fraction of groundwater inflow to deep recharge (DEEPFR).

Model limitations include errors related to model conceptualization and parameter variability, lack of data to better quantify certain model inputs such as rainfall and irrigation, and measurement errors. The models that were developed for these relatively large subwatersheds represent a simplified understanding of the hydrologic processes of the middle Nueces River watershed. Because intense, isolated storms are common in south Texas, rainfall can vary greatly over a short distance. Uncertainty regarding the degree to which available rainfall data represent actual rainfall is potentially the most serious source of error for the middle Nueces River watershed model.

Model-estimated mean annual streamflow yields from the eight subwatersheds ranged from -2.4 to 6.5 inches per year (in/yr), with yields greatest in the Mathis subwatershed and lowest in the Three Rivers subwatershed. The area-weighted mean yield of the eight subwatersheds was $1.12 \mathrm{in} / \mathrm{yr}$ for 1961-2008.

The annual estimates of the water-budget components from two subwatersheds with streams flowing across part of the Carrizo-Wilcox aquifer outcrop area were spatially weighted to determine the estimated amounts of annual rainfall, evapotranspiration, recharge, and surface runoff for the Carrizo-Wilcox aquifer outcrop area during 1961-2008. The mean annual rainfall on the Carrizo-Wilcox aquifer outcrop area during the 1961-2008 simulation period was approximately $21.7 \mathrm{in}$. Of this rainfall, an annual mean of approximately 20.1 in (about 93 percent) was simulated as evapotranspiration; 1.2 in (about 6 percent) was simulated as groundwater recharge; and 0.5 in (about 2 percent) was simulated as surface runoff. Estimated annual groundwater recharge in the Carrizo-Wilcox aquifer outcrop area varied from 0.0 to 5.5 in depending on the amount of rainfall.

\section{References}

Ashworth, J.B., and Hopkins, Janie, 1995, Aquifers of Texas: Texas Water Development Board Report 345, 69 p.

Asquith, W.H., 1998, Depth-duration frequency of precipitation for Texas: Austin, Tex., U.S. Geological Survey Water-Resources Investigations Report 98-4044, $107 \mathrm{p}$.

Berris, S.N., 1995, Conceptualization and simulation of runoff generation from rainfall for three basins in Thurston County, Washington: U.S. Geological Survey Water-Resources Investigations Report 94-4038, 149 p.

Bicknell, B.R., Imhoff, J.C., Kittle, J.L., Jr., Donigian, A.S., and Johanson, R.C., 2001, Hydrological Simulation Program-FORTRAN, user's manual for version 12: Research Triangle Park, N.C., U.S. Environmental Protection Agency, National Exposure Research Laboratory, Office of Research and Development, $843 \mathrm{p}$.

Bidlake, W.R., 2002, Evapotranspiration from selected fallowed agricultural fields on the Tule Lake National Wildlife Refuge, California, during May to October 2000: U.S. Geological Survey Water-Resources Investigations Report 02-4055, 59 p. 
City of Corpus Christi, 2010, City of Corpus Christi official Web site-Lake Corpus Christi and Choke Canyon Reservoir: accessed May 29, 2010, at http://www.cctexas. $\mathrm{com} /$ ? fuseaction $=$ main.view\&page $=1020$.

Chow, V.T., 1964, Handbook of applied hydrology: New York, McGraw-Hill, 1,418 p.

Donigian, A.S., Jr., Bicknell, B.R., and Imhoff, J.C., 1995, Hydrological simulation program-FORTRAN (HSPF), in Singh, V.P., ed., Computer models of watershed hydrology: Highlands Ranch, Colo., Water Resources Publications, p. $395-442$.

Donigian, A.S., Jr., Imhoff, J.C., Bicknell, B.R., and Kittle, J.L., Jr., 1984, Application guide for Hydrological Simulation Program - FORTRAN (HSPF): Athens, Ga., U.S. Environmental Protection Agency, Environmental Research Laboratory, EPA-600/3-84-065, 177 p.

ESRI, 2009, ESRI home page: accessed January 12, 2009, at http://www.esri.com/.

HDR Engineering, 2002, Nueces River Basin section 905(b) analysis reconnaissance report, August 2002: Prepared for the U.S. Army Corps of Engineers, accessed August 19, 2011, at http://www.swf.usace.army.mil/pubdata/notices/ nueces_river_study.asp.

Homer, Collin, Huang, Chengquan, Yang, Limin, Wylie, Bruce, and Coan, Michael, 2004, Development of a 2001 national land-cover database for the United States: Photogrammetric Engineering and Remote Sensing, v. 70, no. 7, p. 829-840.

Kelley, V.A., Deeds, N.E., Fryar, D.G., Nicot, J.P., Jones, T.L., Dutton, A.R., Bruehl, Gabe, Unger-Holtz, Tanya, and Machin, J.L., 2004, Groundwater availability model for the Queen City and Sparta aquifers: Final report prepared for the Texas Water Development Board by INTERA Inc., accessed June 10, 2010, at http://www.twdb.state.tx.us/gam/ qc_sp/QCSP_FinalReport_Part1.pdf.

Larkin, T.J., and Bomar, G.W., 1983, Climatic atlas of Texas: Texas Department of Water Resources, Limited Printing Report LP-192, $151 \mathrm{p}$.

Linsley, R.K., Kohler, M.A., and Paulhus, J.L.H., 1982, Hydrology for engineers ( $3 \mathrm{~d}$ ed.): New York, McGraw-Hill, $512 \mathrm{p}$.

Lizárraga, J.S., and Ockerman, D.J., 2010, Simulation of streamflow, evapotranspiration, and groundwater recharge in the lower San Antonio River Watershed, south-central Texas, 2000-2007: U.S. Geological Survey Scientific Investigations Report 2010-5027, $41 \mathrm{p}$.
Lizárraga, J.S., and Ockerman, D.J., 2011, Simulation of streamflow, evapotranspiration, and groundwater recharge in the Lower Frio River watershed, south Texas, 19612008: U.S. Geological Survey Scientific Investigations Report 2011-5093, 42 p.

Multi-Resolution Land Characteristics Consortium, 2010, National land cover database 2001 (NLCD2001): MultiResolution Land Characteristics Consortium Web site, accessed May 25, 2010, at http://www.mrlc.gov/nlcd.php.

Nash, J.E., and Sutcliffe, J.V., 1970, River flow forecasting through conceptual models, part $1-\mathrm{A}$ discussion of principles: Journal of Hydrology, v. 10, no. 3, p. 282-290.

National Climatic Data Center, 2009, Weather/climate events, information and assessments - Weather/climate data and products: accessed February 26, 2009, at http://www.ncdc. noaa.gov/oa/climate/severeweather/extremes.html.

Natural Resources Conservation Service, 2010, Soil Survey Geographic (SSURGO) database for Bee, Dimmit, Duval, Karnes, Kinney, La Salle, Live Oak, Maverick, McMullen, Medina, Uvalde, Webb, Wilson, and Zavala Counties, Texas: accessed May 15, 2010, at http://soildatamart.nrcs. usda.gov/.

Nueces River Authority, 2011, Lake Corpus Christi evaporation, 1999-2011: accessed August 8, 2011, at http://www. nueces-ra.org/CP/CITY/month.php.

Ockerman, D.J., 2002, Simulation of runoff and recharge and estimation of constituent loads in runoff, Edwards aquifer recharge zone (outcrop) and catchment area, Bexar County, Texas, 1997-2000: U.S. Geological Survey WaterResources Investigations Report 02-4241, 31 p.

Ockerman, D.J., 2005, Simulation of streamflow and estimation of recharge to the Edwards aquifer in the Hondo Creek, Verde Creek, and San Geronimo Creek watersheds, south-central Texas, 1951-2003: U.S. Geological Survey Scientific Investigations Report 2005-5252, 37 p.

Ockerman, D.J., 2007, Simulation of streamflow and estimation of groundwater recharge in the upper Cibolo Creek watershed, south-central Texas, 1992-2004: U.S. Geological Survey Scientific Investigations Report 2007$5202,34 \mathrm{p}$.

Ockerman, D.J., and McNamara, K.C., 2003, Simulation of streamflow and estimation of streamflow constituent loads in the San Antonio River watershed, Bexar County, Texas, 1997-2001: U.S. Geological Survey Water-Resources Investigations Report 03-4030, 37 p.

Ockerman, D.J., and Roussel, M.C., 2009, Simulation of streamflow and water quality in the Leon Creek watershed, Bexar County, Texas, 1997-2004: U.S. Geological Survey Scientific Investigations Report 2009-5191, 50 p. 
Scanlon, B.R., Dutton, Alan, and Sophocleous, Marios, 2003, Groundwater recharge in Texas: Austin, The University of Texas, Bureau of Economic Geology; Lawrence, Kansas Geological Survey, $80 \mathrm{p}$.

Slattery, R.N., Asquith, W.H., and Ockerman, D.J., 2011, Rainfall and evapotranspiration data for southwest Medina County, Texas, August 2006-December 2009: U.S. Geological Survey Data Series 554, 28 p. (Appendix available online at $\mathrm{http}: / /$ pubs.usgs.gov/ds/554/.)

Smith, J.A., 1992, Precipitation, in Maidment, D.R., ed., Handbook of hydrology: New York, McGraw-Hill, p. 3.1-3.47.

Texas Commission on Environmental Quality, 2010, Water rights database and related files: Texas Commission on Environmental Quality Web site, accessed December 20, 2010, at http://www.tceq.state.tx.us/permitting/water supply/water_rights/wr_databases.html.

Texas Natural Resource Conservation Commission, 2001, An agreed order amending the operational procedures and continuing an advisory council pertaining to Special Condition 5.B.: Texas Natural Resource Conservation Commission Certificate of Adjudication No. 21-3214, docket no. 2001-0230, accessed June 11, 2010, at http:// www.cctexas.com/files/g17/2001\%20Agreed\%20Order.pdf.

Texas Water Development Board, 2002, Volumetric survey of Lake Corpus Christi Reservoir: accessed May 29, 2010, at http://www.twdb.state.tx.us/hydro_survey/ CorpusChristti2002/CorpusChristi_rpt.pdf.

Texas Water Development Board, 2003, Volumetric survey of Lake Corpus Christi reservoir: Texas Water Development Board Report prepared for the City of Corpus Christi, accessed June 11, 2010, at http://www.twdb.state.tx.us/ hydro_survey/chokecanyon/ChokeRPT.pdf.
Texas Water Development Board, 2007, Surface water resources, chap. 6 of Water for Texas, 2007: Texas Water Development Board Web site, accessed May 21, 2011, at http://www.twdb.state.tx.us/publications/State_Water_ Plan/2007/2007StateWaterPlan/CHAPTER\%206\%20 FINAL_112906.pdf.

U.S. Census Bureau, 2009, Population Estimates ProgramAnnual estimates of the population of metropolitan and micropolitan statistical areas, April 1, 2000 to July 1, 2009 (CBSA-EST2009-01): accessed June 11, 2010, at http:// www.census.gov/popest/data/metro/totals/2009/index.html.

U.S. Environmental Protection Agency, 2004, Clean watersheds needs survey (CWNS) - CWNS 2004 data: U.S. Environmental Protection Agency, Water Science and Technology database, accessed June 11, 2010, at http:// water.epa.gov/scitech/datait/databases/cwns/2004reportdata. $\mathrm{cfm}$.

U.S. Environmental Protection Agency, 2007, Better assessment science integrating point and non-point sources (BASINS): accessed March 12, 2008, at http://www.epa. gov/waterscience/basins/b3webdwn.htm.

U.S. Geological Survey, 2001, Rocky Mountain Mapping Center-Elevation program: accessed September 1, 2008, at http://rockyweb.cr.usgs.gov/elevation/.

U.S. Geological Survey, 2011, USGS water data for Texas: National Water Information System, Web interface (NWISWeb) data, accessed December 2, 2011, at http:// waterdata.usgs.gov/tx/nwis/nwis.

Zarriello, P.J., and Ries, K.G., III, 2000, A precipitation-runoff model for analysis of the effects of water withdrawals on streamflow, Ipswich River Basin, Massachusetts: U.S. Geological Survey Scientific Investigations Report 20004029, $99 \mathrm{p}$. 

